\title{
REVIEW OF JAPANESE FISHES OF THE GENUS NEOCLINUS WITH DESCRIPTION OF TWO NEW SPECIES AND NOTES ON HABITAT PREFERENCE
}

\author{
$\operatorname{AUTHOR}(\mathrm{S})$ : \\ Fukao, Ryuzo
}

CITATION:

Fukao, Ryuzo. REVIEW OF JAPANESE FISHES OF THE GENUS NEOCLINUS WITH

DESCRIPTION OF TWO NEW SPECIES AND NOTES ON HABITAT PREFERENCE.

PUBLICATIONS OF THE SETO MARINE BIOLOGICAL LABORATORY 1980, 25(1-4): 175-209

ISSUE DATE:

1980-02-29

URL:

http://hdl.handle.net/2433/175985

RIGHT: 


\title{
REVIEW OF JAPANESE FISHES OF THE GENUS NEOCLINUS WITH DESGRIPTION OF TWO NEW SPEGIES AND NOTES ON HABITAT PREFERENGE
}

\author{
RYuzo FUKAO \\ Department of Fisheries, Kyoto University, Kyoto \\ With Text-figures $1-15$, Tables $1-8$ and Plates $\overline{I-I I}$
}

\section{Introduction}

The genus Neoclinus was considered the most primitive member of the subfamily Chaenopsinae which is the most primitive offshoot of the family Blenniidae (Hubbs, 1952). Springer (1955) pointed out certain discrepancies in Hubbs' classification. He removed the Chaenopsinae from the Blenniidae and placed it under the Clinidae. $\mathrm{He}$ also considered the Neoclinus as the most primitive member of the subfamily and tentatively estimated that it derived from ancestors of the tribe Palaclinidi of the clinid subfamily Labrisominae. Stephens (1963) separated the family Chaenopsidae from the Clinidae, though some authors use the subfamily Chaenopsinae belonging to the family Clinidae (e.g., Robins and Randall, 1965; Smith-Vaniz and Palacio, 1974). He excluded the Neoclinus from the Chaenopsidae and placed it under the Clinidae, based on the characters such as 4 circumorbital bones, scaled body and well developed lateral line. According to his description, Ghaenopsidae has 2 circumorbital bones (with an exception of Mccoskerichthys sandae which has 4 circumorbital bones), scaleless body and no lateral line. He also thought that the genus Neoclinus occupies a rather isolated position in the family, and is intermediate between the clinids and the chaenopsids in some characters.

The genus Neoclinus was revised by Hubbs (1953). In his revision this genus comprises four species: $N$. stephensae Hubbs: $N$. uninotatus Hubbs; $N$. blanchardi Girard: $N$. bryope (Jordan and Snyder). The former three species are known from California and the last one from Japan. He stated that this genus either originated in or migrated from the New World tropics to the coasts of California, from where $N$. bryope emigrated to Japan through the Aleutians during an interglacial period.

In the course of my study on the blennioid fishes, I collected two blennioid species believed to be new to science from the rocky reef around the Seto Marine Biological Laboratory, Shirahama, Japan. These two species have 4 circumorbital bones,

1) Contributions from the Seto Marine Biological Laboratory, No. 656.

Publ. Seto Mar. Biol. Lab., XXV (1/4), 175-209, 1980.

(Article 13) 
partly scaled body, and well developed lateral line, and are referable to the genus Neoclinus described by Hubbs (1953). In this paper, I describe these two species as the members of the genus Neoclinus and redescribe $N$. bryope which also lives in the rocky reef around the laboratory. I also refer to the habitats of these three Japanese species of Neoclinus.

\section{Materials and Methods}

Underwater observations and samplings were made by using SCUBA around the Seto Marine Biological Laboratory which is located at the mouth of Tanabe Bay on the

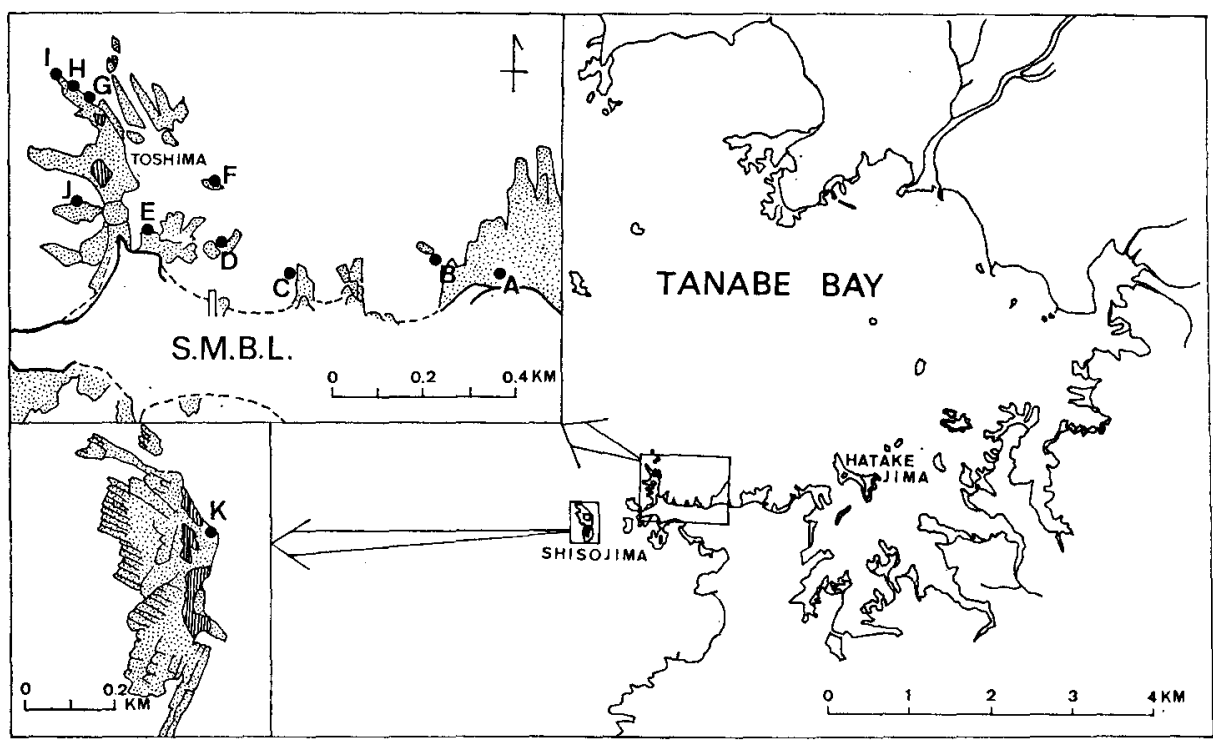

Fig. 1. Study area and stations. A-K show stations; dotted area shows rocky reef; shadowed area shows rocky reef exposed at high tide; broken line shows sandy beach.
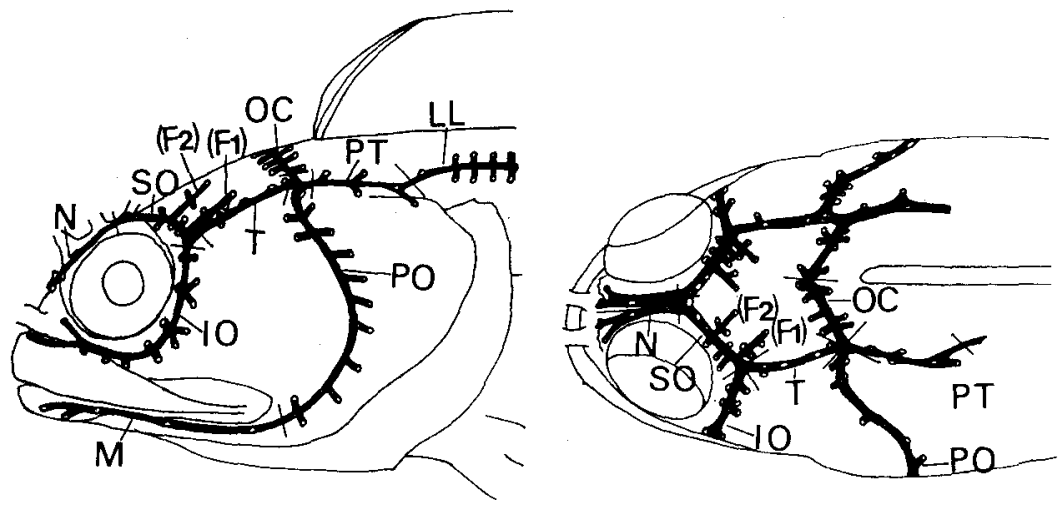

Fig. 2. Diagrammatic illustration of cephalic sensory pore series in Neoclinus bryope. IO: infraorbital series; LL: lateral line; $M$ : mandibular series; $N$ : nasal series; OC: occipital series; PO: preoperclar series; PT : posttemporal series; $\mathrm{SO}$ : supraorbital series; $\mathrm{T}$ : temporal series; (FI): frontal 1 series; $(\mathrm{F} 2)$ : frontal 2 series. 

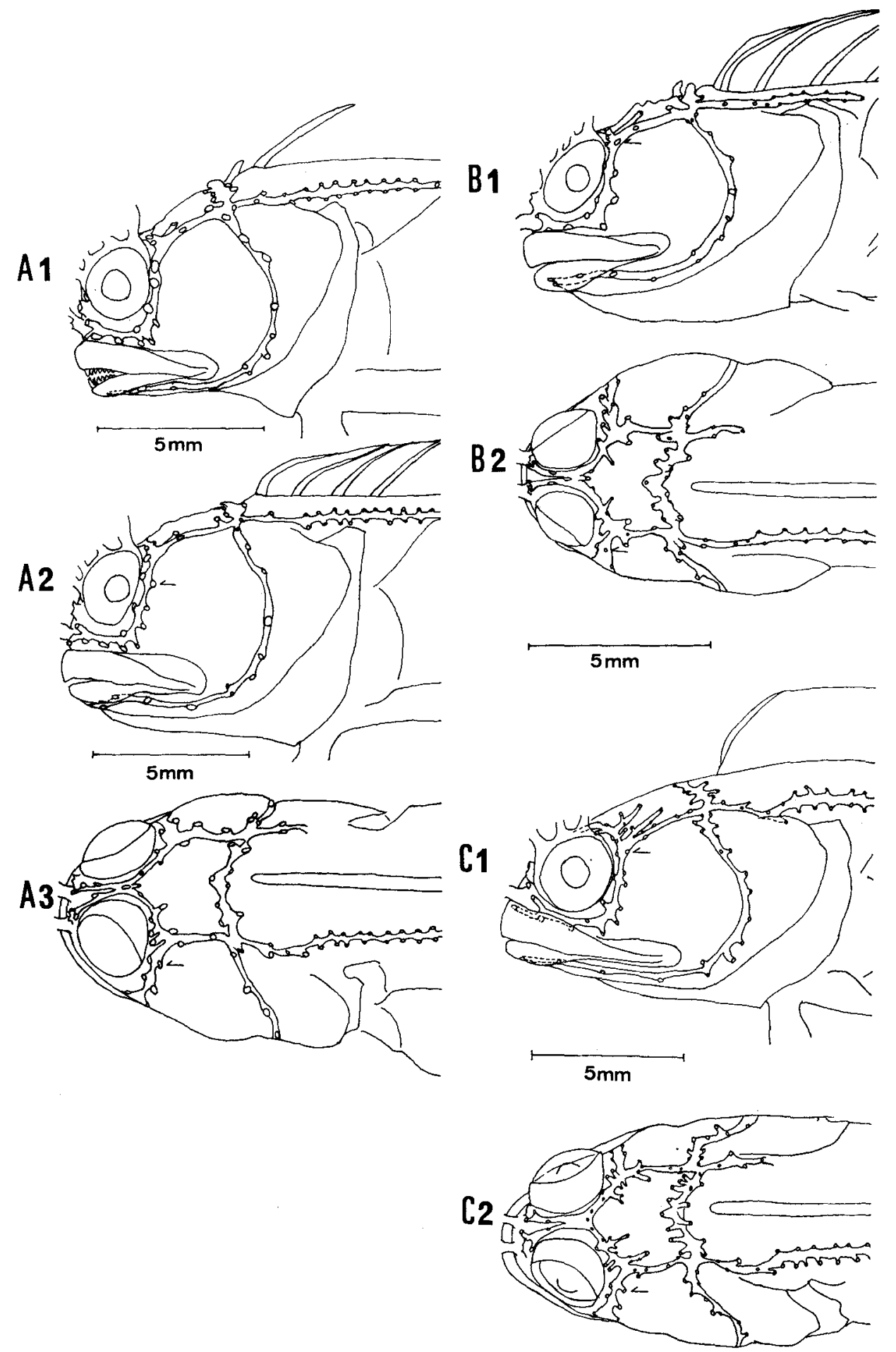

Fig. 3. 
west coast of Kii Peninsula (Fig. 1, approximately $33^{\circ} 41^{\prime} \mathrm{N}$ and $135^{\circ} 20^{\prime} \mathrm{E}$ ). All the specimens used in this study were caught with anesthetic quinaldine and dip net.

Except as noted below, the methods of the counts and the measurements used in this paper followed Hubbs and Lagler (1958). The body depth is the distance between the base of pelvic fin and the closest point on the dorsal contour of body. The opercular membrane is excluded from the measurement of the head length and the postorbital length of head. The head width is the greatest dimension of the cheek. One short splintlike spine of the pelvic fin bound into investing membrane of the first soft ray is usually visible only after dissection or staining, but is included in the pelvic fin count.

All measurements were made with needle point dividers and specimens were measured to the nearest $0.1 \mathrm{~mm}$. Proportion of each measurement is expressed in thousandths of standard length. Ranges and average values of proportional measurements are given for each species of specimens. In the case where the proportional changes with growth are observed, the relations between those proportional measurements and the standard lengths are shown in figures.

Circumorbital bones, nasals, teeth, caudal skeletons and caudal procurrent rays were examined after being cleared and stained by alizarine-red, and gill rakers on the first arch of left side were examined after dissection. Those were examined for five specimens of each species. Extremely thin delicate embedded scales are usually difficult to observe and two specimens for each species were examined after being stained by alizarine-red. Anterior lateral line scales are also difficult to observe, and were counted with the aid of the lateral line pores. Cephalic sensory pore series investigated in this study are shown in Fig. 2. Typical pore patterns and lateral line canal on head for three Japanese species are given in Fig. 3. Method for manifestation of these pores and canals used in this study followed Jakubowsky (1967). Pore counts were made on left side of each individual. Terminology for arrangement of orbital cirri is shown in Fig. 4. Drawings were made with the aid of a camera lucida.

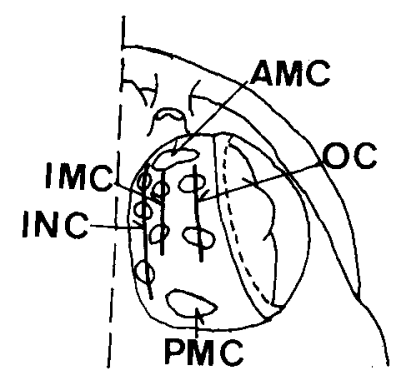

Fig. 4. Schematic drawing of the arrangement of the orbital cirri in N. toshimaensis. AMC: anteriormost cirrus; IMC: intermediate cirri; INC: inner cirri; OC: outer cirri; PMC: posteriormost cirrus.

Fig. 3. Comparison of cephalic sensory pores and lateral line on head in three Japanese species of Neoclinus. Al: N. toshimaensis, FAKU 49484-b, $52.4 \mathrm{~mm}$ S.L.; A2, A3: N. toshimaensis, FAKU 48924-a, $54.6 \mathrm{~mm}$ S.L.; B1, B2: $N$. lacunicola, FAKU 49482-a, $48.4 \mathrm{~mm}$ S.L.; C1,C2: N. bryope, FAKU 48933, $51.2 \mathrm{~mm}$ S.L. 
Collections bearing the abbreviation FAKU are deposited in the Department of Fisheries, Faculty of Agriculture, Kyoto University.

\section{Key to the Japanese Species of the Genus Neocliuns Girard, 1858}

1a. Nuchal cirri absent; one ocellus on membrane between first two dorsal spines N. bryope (Jordan and Snyder)

1b. Nuchal cirri present; no ocellus on dorsal fin .2

2a. Orbital cirri 9 to 11 (mostly 9) arranged in 3 rows in middle part; dorsal fin elements 41 to 45 (mostly 44); anal fin elements 30 to 33 (mostly 31 or 32); total vertebrae 49 to 51 (mostly 50 ).......................... toshimaensis n. sp.

2b. Orbital cirri 6 to 7 (mostly 7 ) arranged in 2 rows; dorsal fin elements 38 to 42 (mostly 41); anal fin elements 28 to 31 (mostly 29 or 30 ); total vertebrae 45 to 48 (mostly 46 or 47 )..................................... lacunicola $\mathrm{n}$. sp.

\section{Description of Three Japanese Species of Neoclinus \\ Neoclinus toshimaensis n. sp. \\ (Japanese name: Toshima-koke-ginpo)}

(Pl. I-A)

Neoclinus sp. Masuda, Araga and Yoshino, 1975: 262-263

Holotype: FAKU 48522, adult male, $59.1 \mathrm{~mm}$ in standard length, collected by Ryuzo Fukao; April 12, 1975; rocky reef of Toshima, at the mouth of Tanabe Bay, Wakayama Prefecture; about $2 \mathrm{~m}$ in depth.

Paratypes: FAKU 48226, 1 male, $58.9 \mathrm{~mm}$; December 2, 1973. FAKU 48523, 2 young and 1 female, 29.1-49.3 mm; April 14, 1975. FAKU 48524, 1 young, 34.7 mm; April 16, 1975. FAKU 48924, 2 males and 2 females, 45.3-58.2 mm; August 12, 1975. FAKU 48932, I male, $50.6 \mathrm{~mm}$; April 29, 1975. FAKU 48934, 1 young and 1 male, $37.2 \mathrm{~mm}$ and $53.8 \mathrm{~mm}$; April 29, 1975. FAKU 48953, 1 female, $53.8 \mathrm{~mm}$; April 12, 1975. FAKU 49484, 1 young, 4 males and 1 female, 31.1-55.5 mm; May 19, 1977. FAKU 49485, 2 males, $53.0 \mathrm{~mm}$ and $54.9 \mathrm{~mm}$; May 20, 1977. FAKU 49506, 1 young and 1 male, $32.5 \mathrm{~mm}$ and $40.0 \mathrm{~mm}$; June 13, 1977. FAKU 49507, 3 young, 30.6-38.8 mm; June 13, 1977. FAKU 49513, 3 young, 2 males and 1 female, 34.9-41.1 mm; June 27, 1977. Localities of all the paratypes are the same as that of holotype.

\section{Description}

Counts, measurements and proportions of holotype are shown in Table 1. Frequency distributions for each count are shown in Tables 2 to 5 . Ranges and mean values of proportional measurements are shown in Table 6 . Relative growth of some parts of body are shown in Figs. 5 to 12 .

Body rather elongate, compressed, tapering gently from its deepest point (somewhere between 3rd and 9th dorsal spines) to caudal peduncle. Caudal peduncle short 
and deep. Head rather short, nearly round in cross-section posteriorly, somewhat compressed toward tip of snout. Snout short and blunt, shorter than orbit length. Eye anterior and dorsal; lens spherical. Interorbital area narrow, at its narrowest point about equal to one-half length of orbit, with raised fleshy marginal ridges; 1 wartlike protuberance projecting from anteriormost part of each marginal ridge. Circumorbi-

Table 1. Counts, measurements and proportions of holotypes of two new species.

\begin{tabular}{|c|c|c|}
\hline & $\begin{array}{l}N . \text { toshimaensis } \\
\text { FAKU-48522 }\end{array}$ & $\begin{array}{l}\text { N. lacunicola } \\
\text { FAKU-49521 }\end{array}$ \\
\hline Sex & male & male \\
\hline \multicolumn{3}{|l|}{ Counts } \\
\hline Dorsal rays & $\mathrm{XXV}, 18$ & XXIII, 19 \\
\hline Anal rays & II, 29 & II, 27 \\
\hline Pectoral rays & $14-14$ & $13-13$ \\
\hline Pelvic rays & I, 3-I, 3 & I, 3-I, 3 \\
\hline Caudal rays & $7+6=13$ & $7+6=13$ \\
\hline Branchiostegals & $6-6$ & $6-6$ \\
\hline Vertebrae & $14+36=50$ & $13+33=46$ \\
\hline \multicolumn{3}{|c|}{ Measurements, in mm (thousandths of S.L.) } \\
\hline Standard length & 59. $1(1.000)$ & $48.8(1.000)$ \\
\hline Total length & $66.8(1.130)$ & $55.1(1.129)$ \\
\hline Body depth & $8.9(.15 \mathrm{l})$ & $7.1(.145)$ \\
\hline Caudal peduncle depth & $3.9(.066)$ & $3.1(.064)$ \\
\hline Caudal peduncle length & $3.7(.063)$ & $2.8(.057)$ \\
\hline Predorsal length & $8.7(.147)$ & $7.6(.156)$ \\
\hline Preanal length & $25.1(.425)$ & $20.0(.410)$ \\
\hline Anal origin to pelvic insertion & $14.3(.242)$ & $11.3(.233)$ \\
\hline Head length & $11.6(.196)$ & $10.0(.205)$ \\
\hline Head width & $9.0(.152)$ & $6.9(.141)$ \\
\hline Snout length & $2.5(.042)$ & $1.9(.039)$ \\
\hline Postorbital length of head & $7.4(.125)$ & $6.5(.133)$ \\
\hline Orbit to angle of preopercle & $5.6(.095)$ & $4.2(.086)$ \\
\hline Orbital length & $2.8(.047)$ & $2.1(.043)$ \\
\hline Upper jaw length & $6.2(.105)$ & $5.0(.102)$ \\
\hline Dorsal fin base length & $49.2(.832)$ & $40,9(.838)$ \\
\hline Soft dorsal fin base length & $18.8(.318)$ & $17.0(.348)$ \\
\hline Anal fin base length & $31.0(.525)$ & $27.4(.561)$ \\
\hline First dorsal spine length & $4.7(.069)$ & $3.1(.064)$ \\
\hline Longest dorsal spine length & $5.7(.096) ; 5$ th & 4. $1(.084) ; 13$ th \\
\hline Longest dorsal ray length & $5.3(.090) ; 10$ th & 5. $0(.102) ; 11$ th \\
\hline First anal spine length & $2.5(.042)$ & $1.9(.039)$ \\
\hline First anal ray length & $3.8(.064)$ & $3.1(.064)$ \\
\hline Longest anal ray length & $4.3(.073) ; 25$ th & $4.0(.082) ; 24$ th \\
\hline Longest pectoral ray length & $7.2(.122) ; 9$ th & $6.1(\cdot 125) ; 9$ th \\
\hline Longest pelvic ray length & $5.2(.096) ; 2 \mathrm{nd}$ & 4. 4(.091); 2nd \\
\hline
\end{tabular}


Table 2. Frequency distributions for dorsal, anal and pectoral elements in Japanese species of Neoclinus.

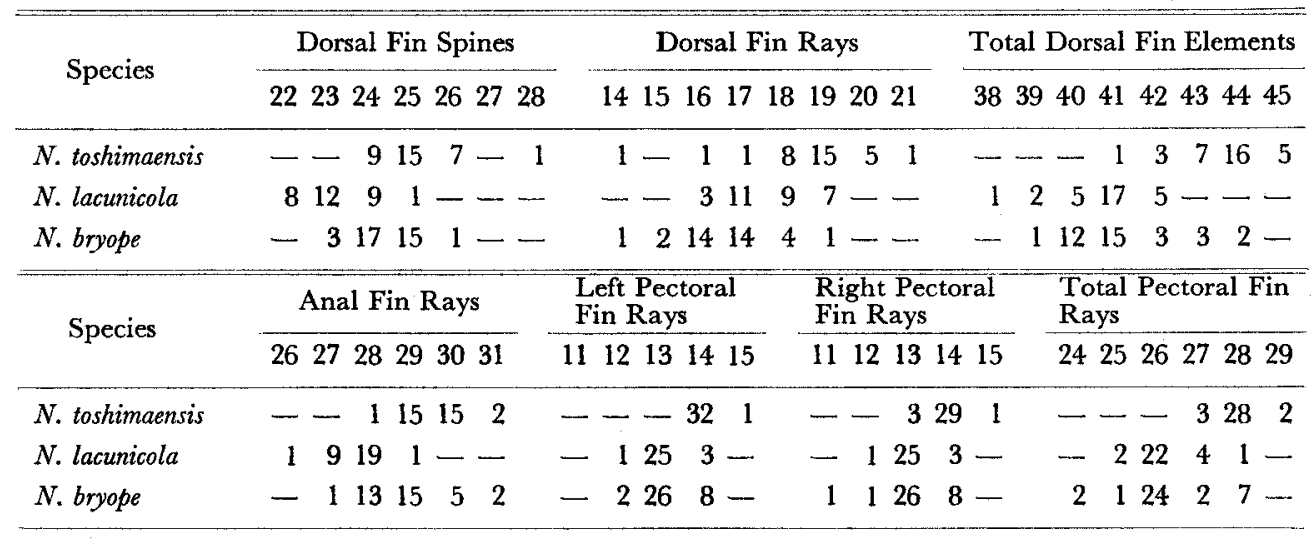

Table 3. Frequency distributions for number of vertebrae in Japanese species of Neoclinus.

\begin{tabular}{|c|c|c|c|c|c|c|c|c|c|c|c|c|c|c|c|}
\hline \multirow{2}{*}{ Species } & \multicolumn{3}{|c|}{$\begin{array}{l}\text { Precaudal } \\
\text { vertebrae }\end{array}$} & \multicolumn{5}{|c|}{ Caudal vertebrae } & \multicolumn{7}{|c|}{ Total vertebrae } \\
\hline & 12 & 13 & 14 & 33 & 34 & 35 & 36 & 37 & 45 & 46 & 47 & 48 & 49 & 50 & 51 \\
\hline$N$. toshimaensis & - & 4 & 25 & - & - & 2 & 21 & 6 & - & - & - & - & 5 & 19 & 5 \\
\hline N. lacunicola & 3 & 27 & 一 & 9 & 19 & 2 & - & - & 1 & 10 & 17 & 2 & - & - & 一 \\
\hline N. bryope & 33 & - & - & 4 & 10 & 14 & 4 & 1 & 4 & 10 & 14 & 4 & 1 & - & - \\
\hline
\end{tabular}

tal bones 4 , stout; lachrymal much larger than the other ones, bounded entire ventral border of eye; dermosphenotic not identifiable. Both right and left nasals articulated each other medially. Frontal with marginal ridge between orbit. Rest part of frontal and parietal slightly uneven. Nasal cirri 2 to 12 on posterior rim of anterior nostril and rarely 1 on anterior rim of posterior nostril; each cirrus thin with 1 to 4 tapered tips. Orbital cirri 9 to 11 (mostly 9), each cirrus much branched and complex (Fig. 4 and $13, \mathrm{~A}$ ); two types of branches, long slender ones with tapered tips and short ones with rounded tips; anteriormost cirrus (AMC) devided into two trunks at broad base bearing both types of branches, long ones on anterior part and short ones on posterior part (Fig. 13, A-a); 2 outer cirri (OC) with both types of branches, long ones outside and short ones inside (rarely without short ones) (Fig. 13, A-b); 2 (rarely 3) intermediate cirri (IMG) and 2 (rarely 3 ) inner cirri (INC) with short branches only (rarely 1 or 2 long ones on IMC) (Fig. 16, A-c); posteriormost cirrus (PMC) and last one of INC similar in shape, height of highest one 0.5 to 1.3 times length of orbit, with both types of branches, long ones posteriorly and short ones anteriorly (Fig. 13, A-d); as a whole, orbital cirri arranged in three rows in middle part and when viewed dorsally long branches encloseing crowds of short ones. Nuchal cirrus 1 on each side of nape, simple, fleshy, elongate conical or sagittal. Occipital region convex, ascending posteriorly, swollen and uneven. Frequently, 1 or 2 fleshy wartlike protuberances projecting from posteromesial part of occipital, just before and between nuchal cirri. 
Upper margin of opercle united to body by thin transparent membrane. Right and left opercular membranes broadly united each other free from isthmus. Branchiostegals 6 . Gill rakers, $5+10=15$ on first arch; those on upper limb short and pointed (last 1 or 2 rudimentary); those on lower limb thin and slender. Lips broad and fleshy, with free margins; free margin of upper lip continuous across the midline, that of lower lip not continuous. Upper jaw reaching beyond hind margin of eye, a distance about equal to orbit length. Six to 10 large, slightly recurved, incisorlike teeth along anterior border of each premaxillary, these teeth becoming smaller posteriorly; a band of small villiform teeth medial to these; 4 to 8 moderate-sized teeth extending along ramus in a single row to half the distance to angle of jaws. Seven to 11 moderate-sized teeth in a single row on palatine; 1 subequal tooth mesial to last third one of this row, present or absent. Five to 7 moderate-sized teeth in an anterior crescentic row on vomer. Seven to 9 large, recurved, incisorlike teeth along anterior border of each mandible, posterior 2 to 4 teeth with pointed tips; a band of small villiform teeth medial to these (less in number and slightly larger in size than those on premaxillary), these on posterior margin of these band somewhat larger; 6 to 9 moderate-sized teeth extending along ramus in a single row to angle. Lateral line on head complete, but canals of (F1) and (F2) series not so elongate as compared with those in N. bryope. Typical pore patterns and lateral line canal on head illustrated in Fig. 3, Al, A2 and A3. Cephalic

Table 4. Frequency distributions for number of cephalic sensory pores in Japanese species of Neoclinus.

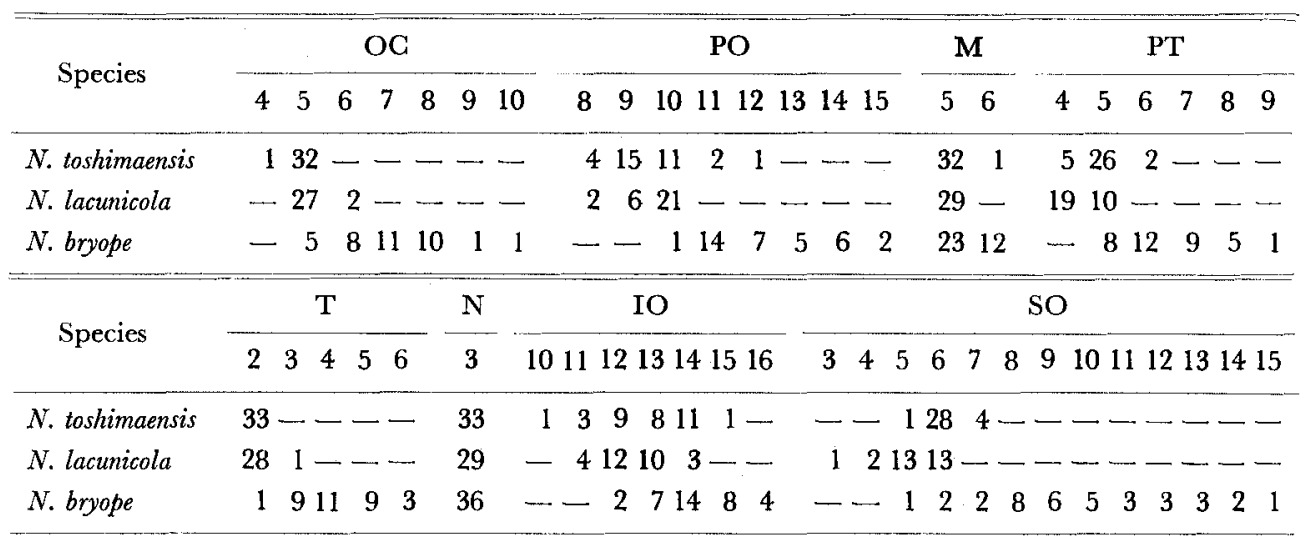

Table 5. Frequency distributions for number of anterior lateral line scales in Japanese species of Neoclinus

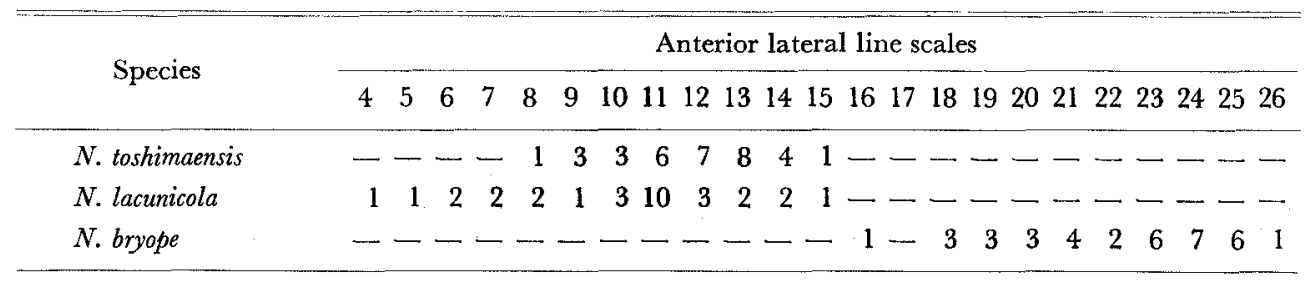


sensory pores large and relatively few in number, distributed generally shown in Fig. 3, A2 and A3; about twice larger pores than ordinal ones in IO series of some specimens (Fig. 3, Al). Pore counts of each series are shown in Table 4. Counts of SO series including those of (F1) and (F2) series.

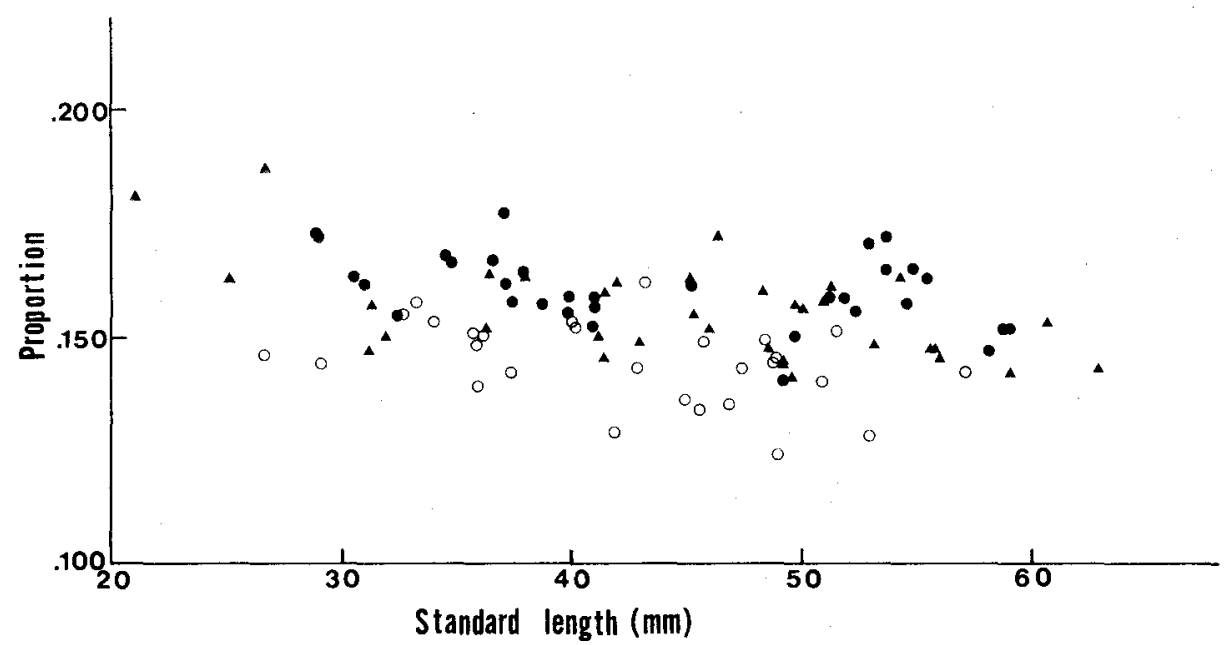

Fig. 5. The relation between proportion of body depth and standard length in three Japanese species of Neoclinus.

: N. toshimaensis; $\bigcirc:$ N. lacunicola; $\mathbf{\Delta}:$ N. bryope.

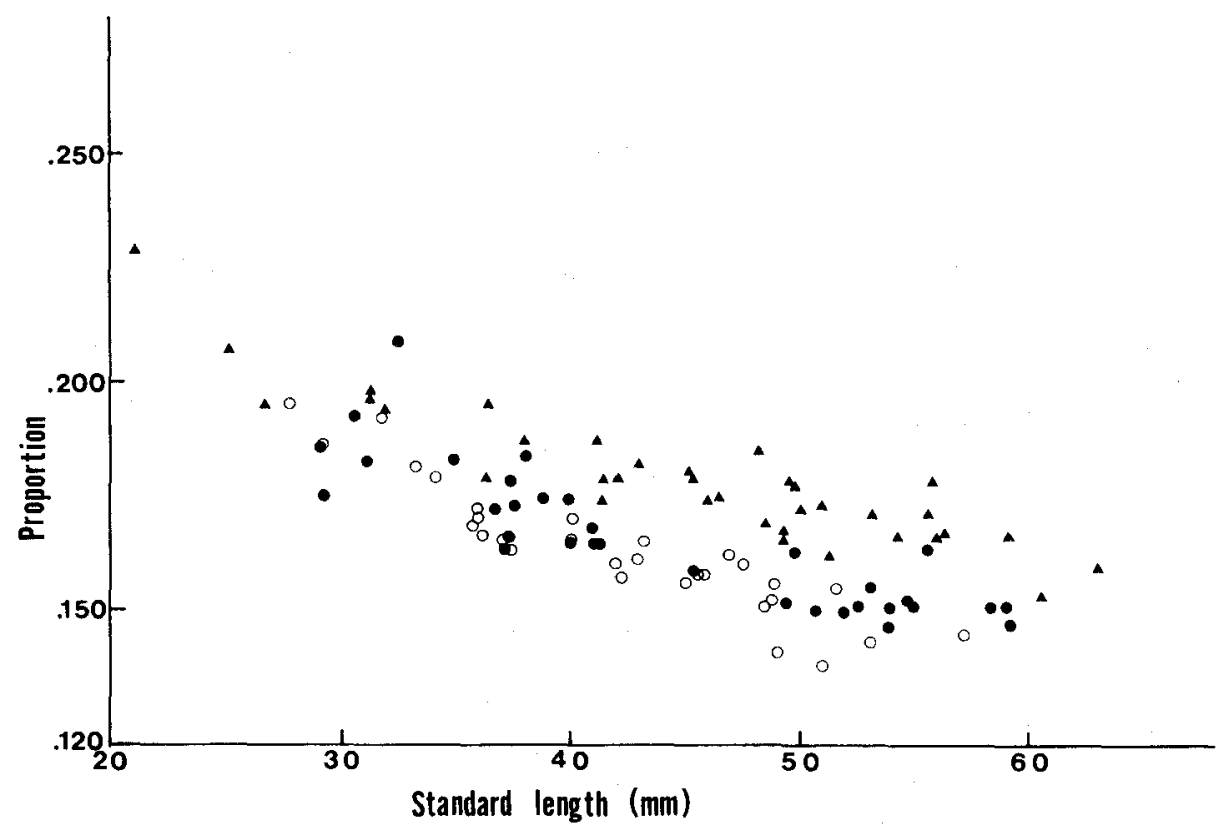

Fig. 6. The relation between proportion of predorsal length and standard length in three Japanese species of Neoclinus.

: N. toshimaensis; $\bigcirc:$ N. lacunicola; $\mathbf{\Delta}:$ N. bryope. 


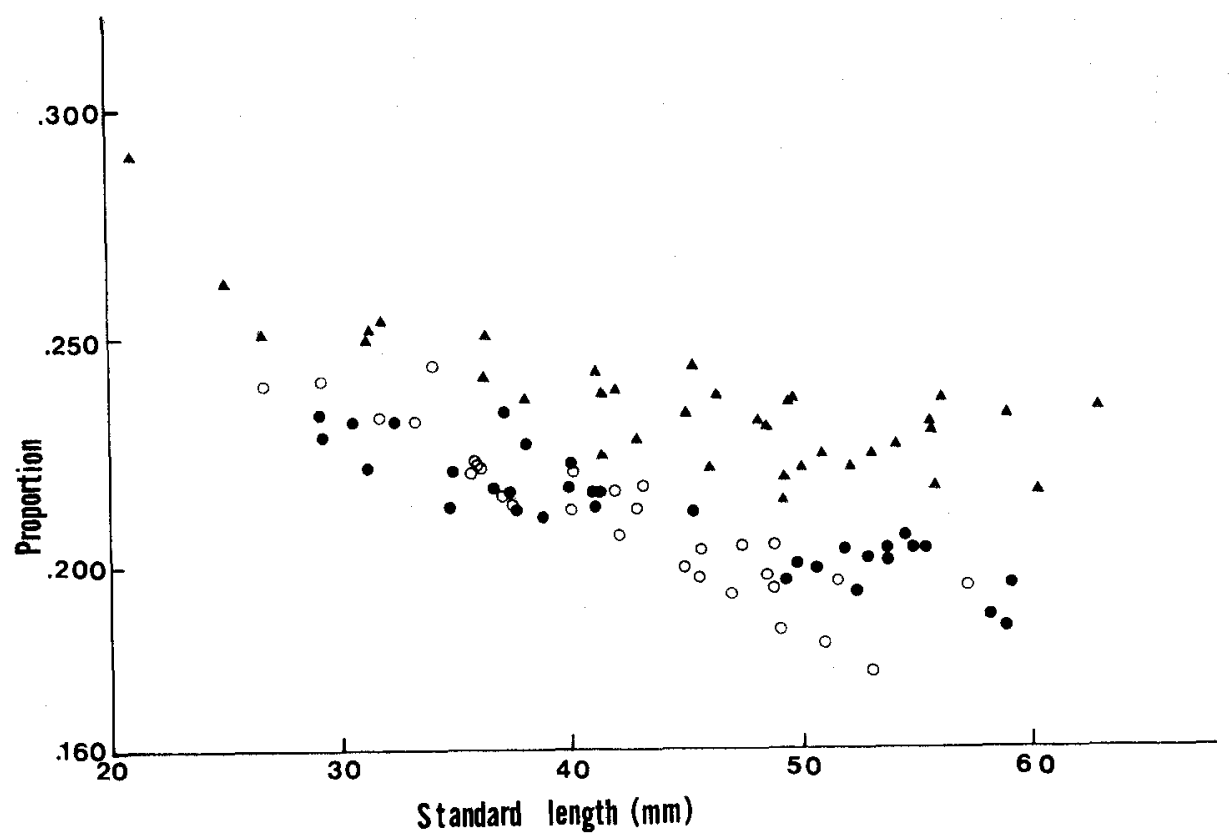

Fig. 7. The relation between proportion of head length and standard length in three Japanese species of Neoclinus.

: N. toshimaensis; $\bigcirc:$ N. lacunicola; A : N. bryope.

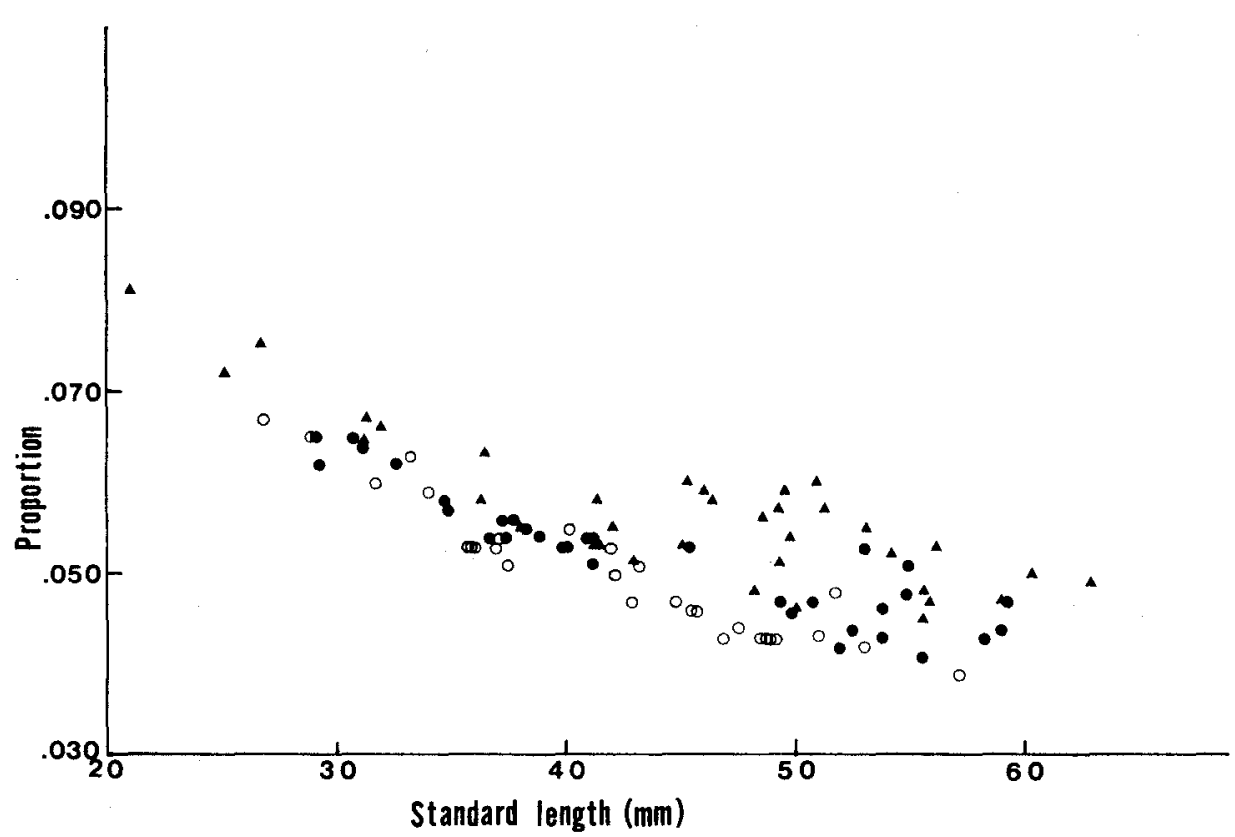

Fig. 8. The relation between proportion of orbit length and standard length in three Japanese species of Neoclinus.

: N.toshimaensis; $\mathrm{O}:$ N. lacunicola; $\mathbf{\Delta}:$ N.bryope. 
Lateral line canal on body running straight posteriorly from upper margin of opercle to a point below 8th to 11 th dorsal spine, from which point turns downward abruptly to midline, and then disappearing; anterior part of lateral line to a point below 5 th to 8 th dorsal spine raised and distinct. Eight to 15 scales in this anterior part (Table

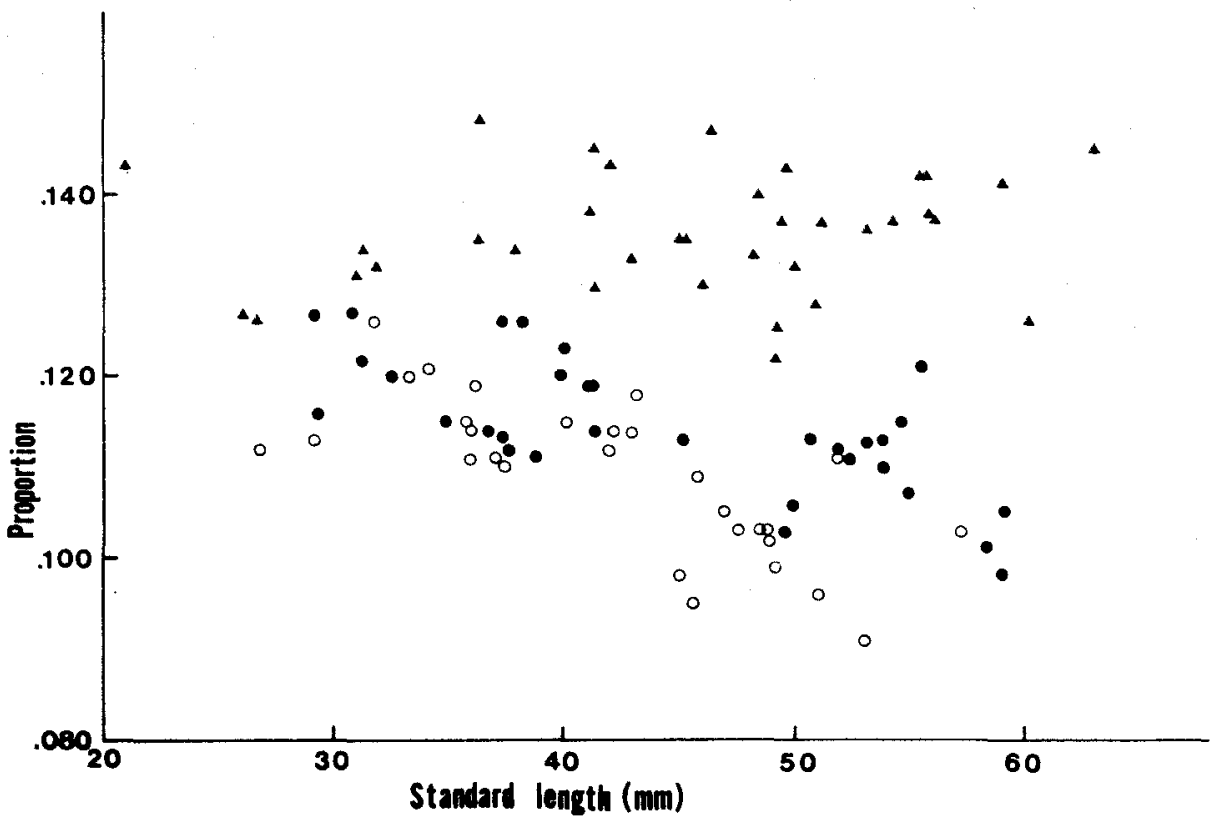

Fig. 9. The relation between proportion of upper jaw length and standard length in three Japanese species of Neoclinus.

: N.toshimaensis; $\mathrm{O}:$ N. lacunicola; $\mathbf{\Delta}:$ N. bryope.

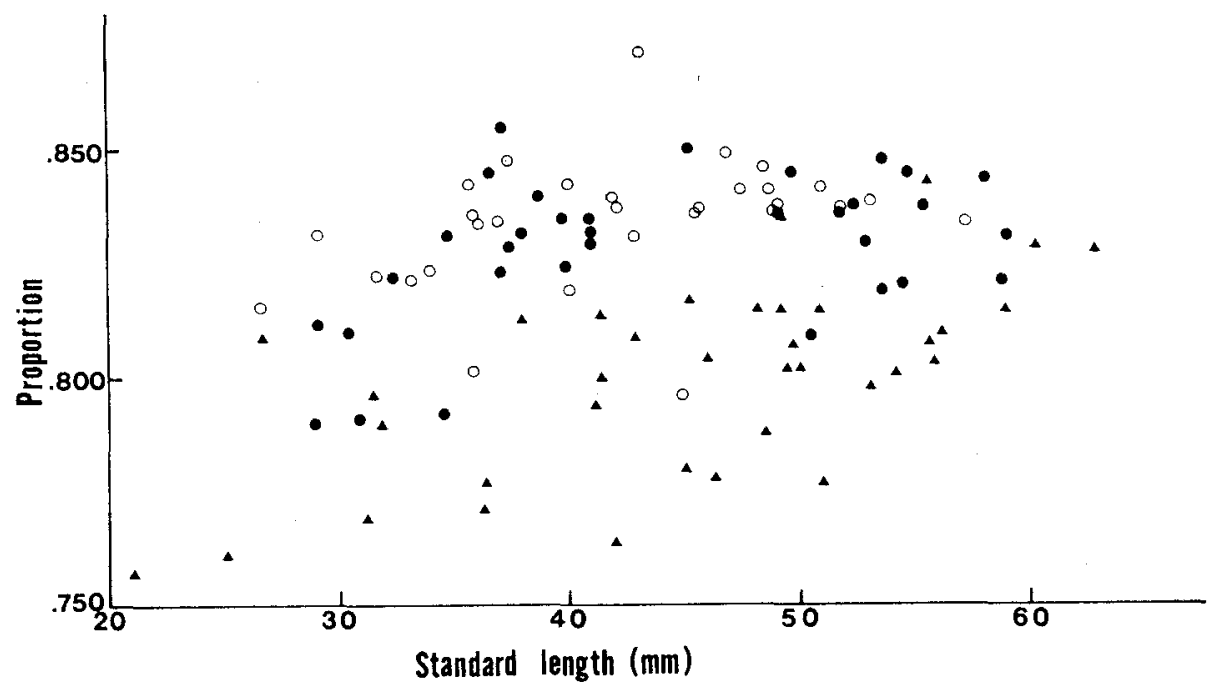

Fig. 10. The relation between proportion of dorsal fin base length and standard length in three Japanese species of Neoclinus.

: N.toshimaensis; $\bigcirc:$. lacunicola; $\mathbf{\Delta}:$ N. bryope. 
5), each with a pore above and below the canal, except for the last 1 to 4 scales with a single large median pore; frequently, these single pores coalescing to form a groove; posterior part becoming difficult to observe, but rarely 2 or 3 minute single pores observed. Head and all fins naked. Belly, subpectoral area and areas covering inclinater muscle of dorsal and anal fins, also scaleless (Fig. 14, A). Moderate-sized cycloid scales with no radii on their posterior margins embedded, nonimbricated and moderately spaced; one somewhat larger scale in each somit on midline of body (Fig. 14, A). Urogenital sinus sexially dimorphic. In male, urogenital sinus opening at the tip of a

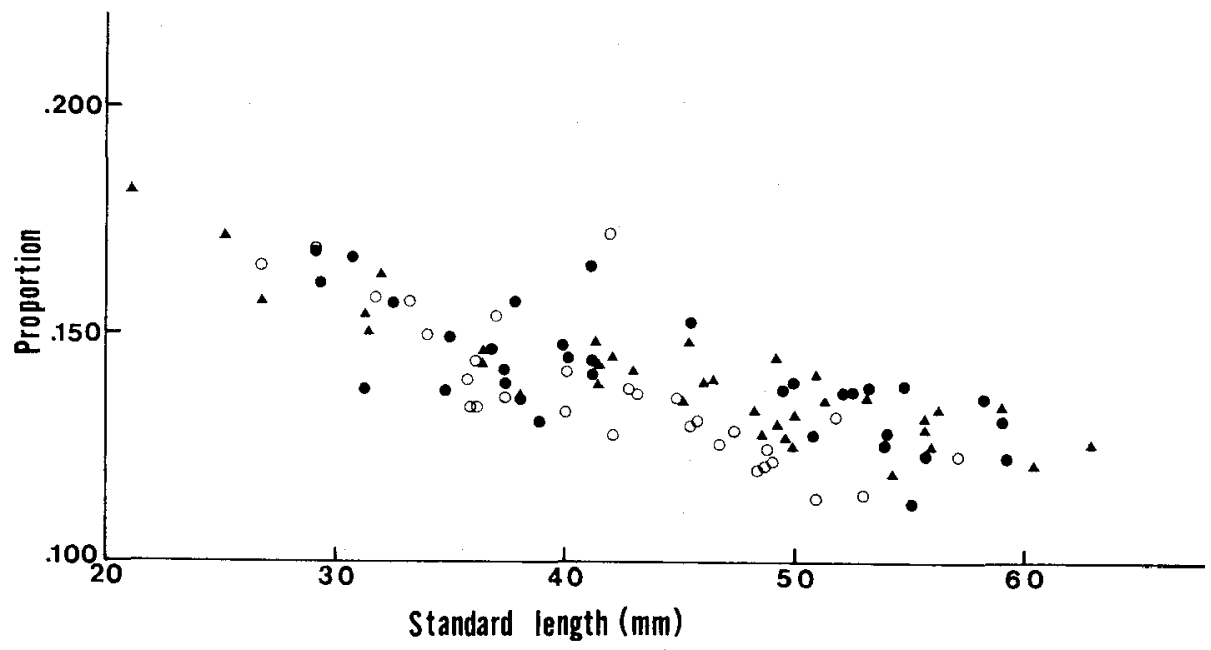

Fig. 11. The relation between proportion of longest pectoral ray length and standard length in three Japanese species of Neoclinus.

: N. toshimaensis; $\bigcirc:$ N. lacunicola; $\mathbf{A}:$ N. bryope.

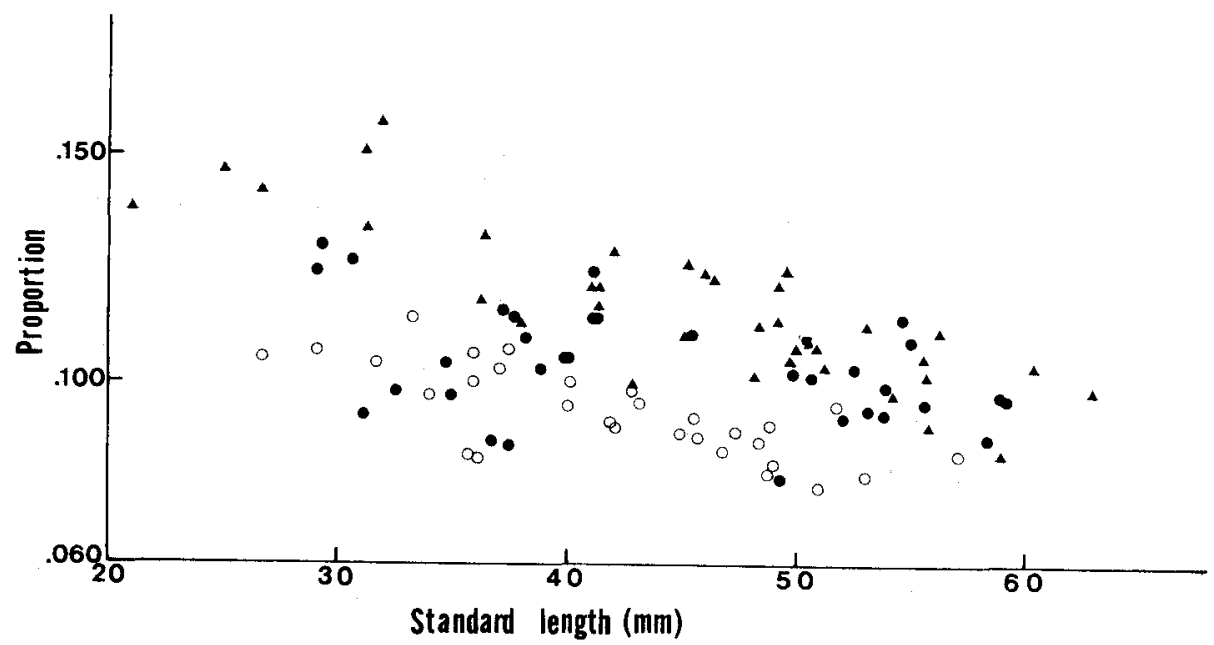

Fig. 12. The relation between proportion of longest pelvic ray length and standard length in three Japanese species of Neoclinus.

: N. toshimaensis; $\bigcirc: N$. lacunicola;

A : N. bryope. 
cone just behind anus; surface of cone smooth; anus surrounded by a wall with radial folds. In female, urogenital sinus opening at the tip of a tubular process and lying close to anus; anterior side of urogenital tube forming posterior wall of anal cavity; urogenital tube with folds and papilla.

Dorsal fin originating on nape, about half way between posterior margins of opercle and of eye. Spinous dorsal fin low; spines increasing in length to 5 th $\sim 10$ th spine, posterior spines approximately equal in length, except for last spine which is slightly shorter than anterior ones but longer than 1st spine; first 2 spines spaced closer together than remaining spines; spines, especially anterior ones, soft and flexible; no membrane on anterior edge of 1 st dorsal spine. Soft dorsal fin slightly higher than spinous dorsal fin; rays increasing in height gradually to 7 th $\sim 9$ th ray, posterior rays approximately equal in length, but last 2 rays shorter; last ray about equal to one-half the length of longest ray, attached only at its base to caudal peduncle by a membrane; fin membranes continuous distally between spines and slightly incised between rays; membrane continuous between spinous and soft dorsal fins, attached to distal tip of terminal spine and to distal fourth of 1 st soft ray. Anal fin slightly lower than dorsal fin; 2 soft and flexible spines shorter and closer together than soft rays; 2nd spine longer than 1st one; 1st soft ray 1.3 to 2 times length of 1 st spine; soft ray increasing in height posteriorly, but last 2 or 3 rays shortened; last anal ray attached only at its base to caudal peduncle by a membrane; fin membranes incised between rays, attached anteriorly to distal tip of ray and posteriorly to distal third of ray. Caudal fin short and rounded, rather truncate in young specimens (less than $40 \mathrm{~mm}$ in S. L.), with $6 \sim 7+13+6 \sim 7$ rays; minimal hypural absent; epiural 1; fin membranes between lower 4 rays slightly incised. Pectoral fin short and rounded, with middle rays longest; lower 5 rays thicker than upper ones; fin membranes more deeply incised ventrally than dorsally. Pelvic fin inserted before pectoral fin origin, consisting of a short thin splintlike spine and 3 soft rays; of the latter, 2 nd ray longest and 3rd ray shortest; membrane between 1 st and 2nd ray deeply incised and that between 2 nd and 3 rd ray slightly incised.

Color in life: Life colors exhibited by this species much variable; yellow to orange, reddish, whitish and blackish phases. These color phases combined with each other to variable extents. The commonest phase, yellow to orange, varying the pattern from almost plain to strongly barred. In typical barred pattern specimens, when viewed from above, 8 to 12 blackish brown or black bands across the dorsal fin base; when viewed from side, these bands often continuous with next ones dorsally and not reaching ventral contour of body; sometimes these bands with pale blotches; the extensions of the bands slightly onto dorsal fin. Ventral side of body slightly darker than dorsal side of body. Dorsal fin membranes colored like body, but sooty in front, gradually becoming lighter posteriorly, frequently, semitransparent; spines and rays with dashes, which grade from dusky brown on anterior spines to bright red on rays; these dashes forming irregular oblique stripes. Anal fin membranes lighter than body with subterminal dusky band; rays reddish, brighter distally and posteriorly. Caudal fin membranes colored like body or semitransparent distally; uppermost and lowermost principal rays with bright red dashes; remainders darker than membrane and tinged with red. 
Pectoral fin membranes lighter than body, or semitransparent; rays reddish, darker ventrally than dorsally. Pectoral fin base with white specklings. Pelvic fin membranes sooty; rays dusky yellow or dusky orange. Head much variable in color, yellow, light tan, dusky yellow, reddish brown or reddish purple; cheek and opercle with very thick white specklings, in addition to these white specklings, frequently, with some deep red ones; jaws and isthmus barred dark and light; branchiostegals also barred dark and light basally, but uniformly red distally; orbital and nasal cirri colored like head with somewhat whitish tips; nuchal cirri somewhat dusky.

In typical plain pattern, body translucent yellow or orange, with trace of bands. Anterior several dorsal spines fully with dark red dashes. Toward posterior, dashes on spines gradually restricted to near the base until spines becoming uniformly red. Dorsal rays uniformly red. Anal fin with subterminal dusky band (rarely absent). Caudal fin rays without dashes. White specklings relatively few on pectoral base, cheek and opercle. Dark bars on jaws and isthmus somewhat obscure, and decreased in number.

All reddish phase specimens barred pattern. Irregular body bands black and their pale interspaces slightly tinged with reddish purple. Belly and near the anal base yellowish. Membranes of anterior dorsal and pelvic sooty. Those of posterior dorsal, anal, caudal and pectorals semitransparent or slightly tinged with reddish purple. Head reddish purple or reddish brown.

Only one whitish phase specimen barred pattern. Irregular body bands black and their interspaces whitish. Belly and near the anal base yellowish. Membranes of anterior dorsal and pelvic sooty. Those of posterior dorsal, anal, caudal and pectorals semitransparent. Head dusky brown.

Only one blackish phase specimen barred pattern. Body bands blackish and their dusky pale interspaces very narrow. Belly and near the anal base blackish, confluented with body bands. Membranes of anterior dorsal and pelvic sooty. Those of posterior dorsal, anal, caudal and pectorals semitransparent, but near the base slightly tinged with yellow. Head blackish.

Etymology: Toshima is the name of an island where the specimen of this species was first collected.

\section{Neoclinus lacunicola $\mathrm{n}$. sp.}

\section{(Japanese name: Iwaana-koke-ginpo)}

\section{(PI. I-B)}

Holotype: FAKU 49521, adult male, $48.8 \mathrm{~mm}$ in standard length, collected by Ryuzo Fukao; June 19, 1977; rocky reef off northern beach of the laboratory; about $3 \mathrm{~m}$ in depth.

Paratypes: FAKU 48403, 1 female, $44.9 \mathrm{~mm}$; May 27, 1973. FAKU 48525, 1 female, $41.9 \mathrm{~mm}$; November 27, 1974. FAKU 48962, 1 male and 1 female, $42.1 \mathrm{~mm}$ and $50.9 \mathrm{~mm}$; July 31, 1975. FAKU 49480, 1 young and 2 females, 31.7-53.0 mm; May 19, 1977. FAKU 49481, 1 young and 3 females, 26.7-57.1 mm; May 18, 1977. 
FAKU 49482, 1 young, 1 male and 1 female, 29.1-48.4 mm; May 20, 1977. FAKU 49483, 2 males and 3 females, 37.0-49.0 mm; May 20, 1977. Localities of above mentioned paratypes are the same as that of holotype. FAKU 49519, 1 male, 40.0 mm; June 13, 1977; rocky reef of Toshima, at the mouth of Tanabe Bay, Wakayama Prefecture; about $3 \mathrm{~m}$ in depth. FAKU 49522, 1 young, $37.4 \mathrm{~mm}$; June 21, 1977. FAKU 49531, 2 young, $33.2 \mathrm{~mm}$ and $34.0 \mathrm{~mm}$; June 27, 1977. FAKU 49533, 3 young and 2 females, 35.7-51.7 mm; July 1, 1977. Localities of above mentioned paratypes are the same as that of FAKU 49519.

\section{Description}

Counts, measurements and proportions of holotype are shown in Table 1. Frequency distributions for each count are shown in Tables 2 to 5 . Ranges and mean values of proportional measurements are shown in Table 6. Relative growth of some parts of body shown in Figs. 5 to 12 .

Body elongate, compressed, tapering very gently from its deepest point (somewhere 2nd to 9 th dorsal spine) to caudal peduncle. Caudal peduncle short and deep. Head short, nearly round in cross section posteriorly, somewhat compressed toward tip of snout. Snout blunt and short, shorter than orbit length. Eye anterior and dorsal; lens spherical. Interorbital area narrow, at its narrowest point about one-third to onehalf length of orbit, with raised fleshy marginal ridges; 1 wartlike protuberance projecting from anteriormost part of each marginal ridge; in only one specimen, from rightside marginal ridge, projecting 2 cirri like orbital cirri. Circumorbital bones 4 , stout; lachrymal much larger than the other ones, relatively slender, bounded entire ventral border of eye; dermosphenotic not identifiable. Right and left nasals articulated each other medially or not (articulated in 3 specimens and separated in 2 specimens). Frontal and parietal slightly uneven. Nasal cirri 0 to 5 on posterior rim of anterior nostril (mostly 3, right side nostril of one specimen without rim and any cirrus); each cirrus thin and slender with 1 to 4 branches. Orbital cirri 6 to 7 (mostly 7) arranged in 2 rows (Fig. 13, B) ; 4 (rarely 3 ) cirri on outer row, 3 (rarely 2 or 4 ) cirri on inner row; each cirrus with short branches (Fig. 13, B-b); sometimes, in addition to short branches, with a few long ones (Fig. 13, B-a); either last cirrus of outer row or that of inner row longest, 0.5 to 1.3 times length of orbit. Fleshy nuchal cirrus 1 on each side of nape, simple, elongate conical or egg-apple like. Occipital region convex, ascending posteriorly, swollen and uneven; sometimes, in front of nuchal cirri, several simple elongate blunt fleshy papilla projecting from this swollen occipital region. Upper margin of opercle united to body by thin, transparent membrane. Right and left opercular membranes broadly united each other free from isthmus. Brachiostegals 6. Gill rakers $5 \sim 6+10 \sim 11=15 \sim 17$ on first arch; those on upper limb short and pointed (last 2 or 3 rudimentary); those on lower limb thin and slender. Lips broad and fleshy, with free margins, free margin of upper lip continuous across the midline, that of lower lip not continuous. Upper jaw reaching beyond hind margin of eye a distance about equal to two-thirds the orbital length. Seven to 10 large slightly recurved, incisorlike teeth along anterior border of each premaxillary, these teeth 

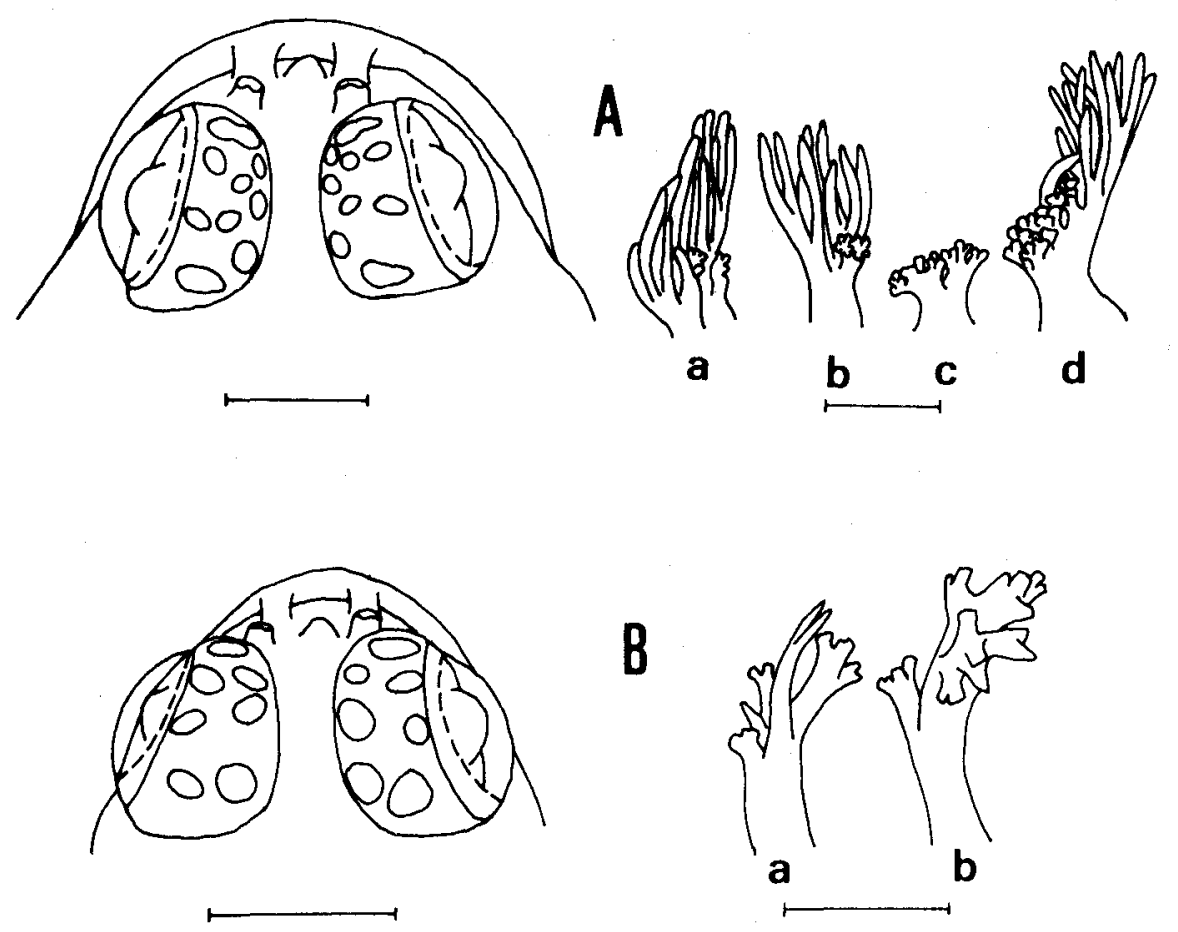

B
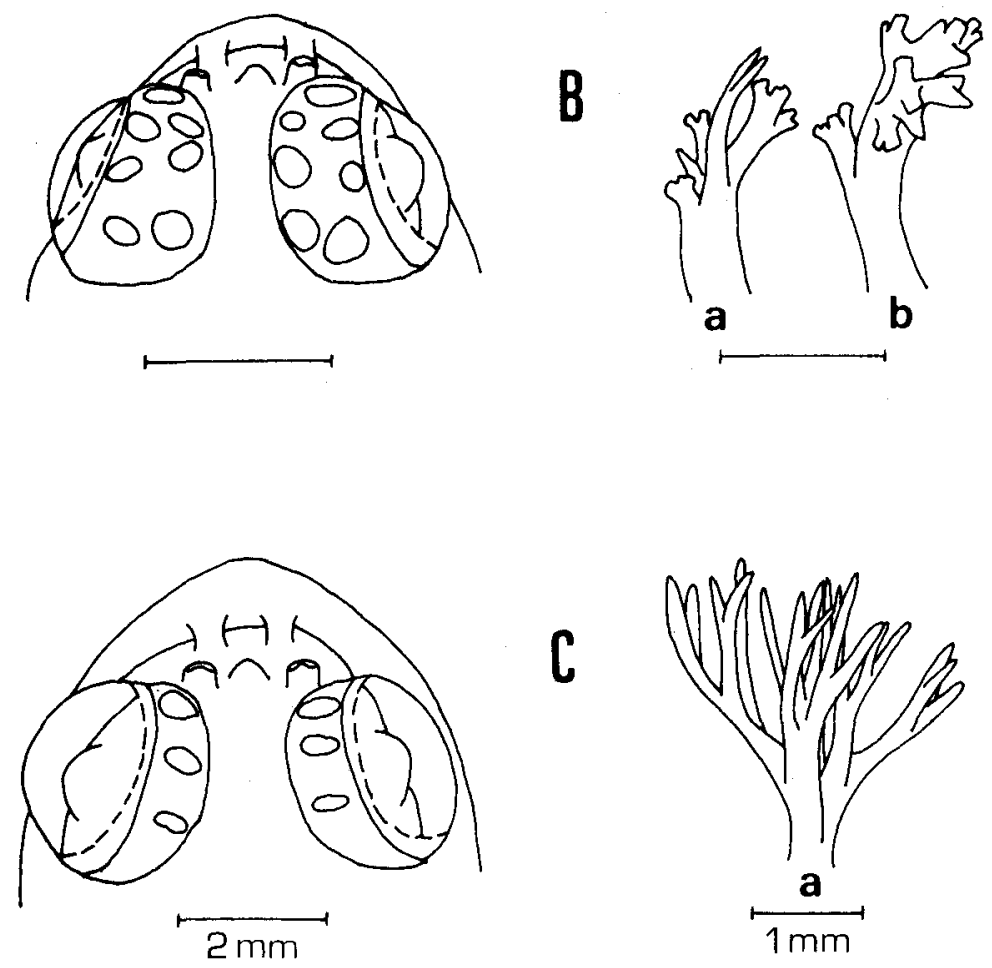

Fig. 13. Comparison of arrangement and shape of orbital cirri in three Japanese species of Neoclinus. A: $N$, toshimaensis, FAKU 49485-a, $54.9 \mathrm{~mm}$ S.L.; A-a: AMC; A-b: 2nd cirrus of OC: A-c: 2nd cirrus of IMG; A-d: PMG. B: N. lacunicola, FAKU 49535-a, $47.2 \mathrm{~mm}$ S.L.; B-a: 2nd cirrus of outer row; B-b; posteriormost cirrus of inner row. C: N. bryope, FAKU 49371-a, $50.9 \mathrm{~mm}$ S.L.; G-a: anteriormost cirrus.

becoming smaller posteriorly; a band of small villiform teeth medial to these; 10 to 13 moderate-sized teeth extending along ramus in a single row to half the distance to angle of jaws. Eight to 10 moderate-sized teeth in a single row on palatine. Five moderatesized teeth in an anterior crescentic row on vomer. Six to 9 large recurved incisorlike 
teeth along anterior border of each mandible, posterior 2 to 4 teeth with pointed tips; a band of small villiform teeth medial to these (less in number and slightly larger in size than those on premaxillary), those on posterior margin of these band somewhat larger; 9 to 12 moderate-sized teeth extending along ramus in a single row to angle of jaws. Lateral line on head complete, but canals of (F1) and (F2) series not so elongate as those in N. bryope. Typical pore pattern and lateral line canal on head illustrated in Fig. 3, B1 and B2. Cephalic sensory pore moderate in size and relatively few in number. Pore counts of each series are shown in Table 4. Counts of SO series including those of (F1) and (F2) series.

Lateral line canal on body running straight posteriorly from upper margin of opercle to a point below 7 th to 8 th dorsal spine, where turns slightly downward and soon becomes invisible; anterior part of lateral line to a point below 3rd to 7th dorsal spine raised and distinct. Four to 15 scales in this anterior part (Table 5), each with a pore above and below the canal, except for last 1 to 4 scales, with a single large median pore; behind this anterior part, mostly, becoming difficult to observe, but rarely 1 or 2 minute, single pore observed. Head and all fins naked. Belly, subpectoral area and areas covering inclinater muscle of dorsal and anal fin, also scaleless (Fig. 14, B). Small cycloid scales with no radii on their posterior margins embedded, nonimbricated and
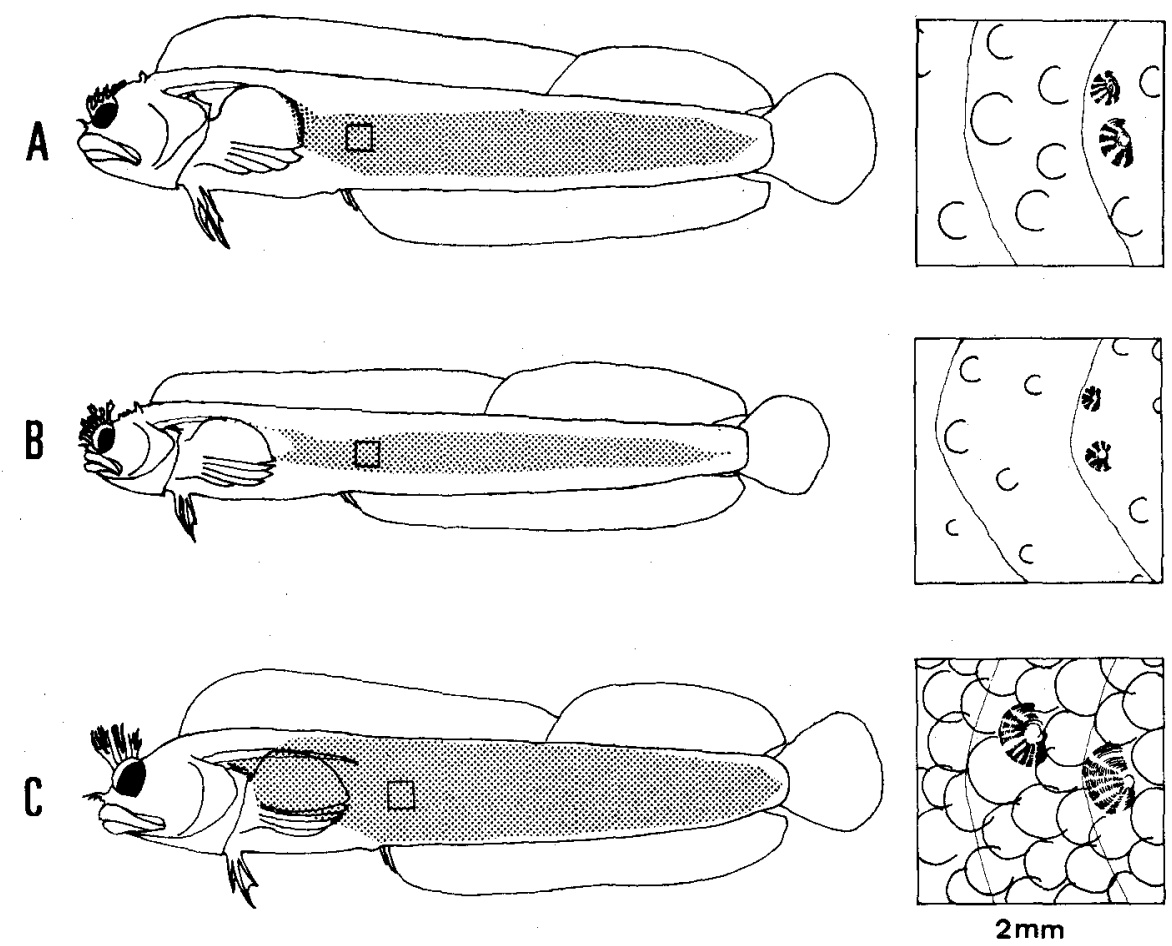

Fig. 14. Comparison of squamation in three Japanese species of Neoclinus. A: N. toshimaensis, FAKU 48924-b, $51.9 \mathrm{~mm}$ S.L.; B: $N$. lacunicola, FAKU 48962-a, 50.9mm S.L.; C: $N$. bryope, FAKU 48933, $51.2 \mathrm{~mm}$ S.L. Dotted areas show scaled portion. Rights are the magnifications of squares in left figures. 
widely spaced; one somewhat larger scale in each somit on midline of body (Fig. 14, B). Urogenital sinus sexially dimorphic. In male, urogenital sinus opening at the tip of a cone jsut behind the anus; surface of cone smooth; anus surrounded by a wall with radial folds. In female, urogenital sinus opening at the tip of a tublar process and lying close to anus; anterior side of urogenital tube forming posterior wall of anal cavity; urogenital tube and anus with folds and papilla.

Dorsal fin originating on nape, about half way between posterior margins of opercle and of eye. Spinous dorsal fin low; spines gradually increasing in length posteriorly, but last 1 or 2 spines slightly shorter (rarely all spines subequal or some middle ones slightly longer); first 3 to 5 spines spaced wider than remaining spines, sometimes first 2 spines closer together and from 2 nd to 4 th or 5 th spines spaced wider than remaining spines (the latter case, more in males than in females but not always); dorsal spines, especially anterior ones, soft and flexible; a thin narrow membrane along anterior edge of first dorsal spine. Soft dorsal fin slightly higher than spinous dorsal fin; rays slightly increasing in height gradually, heighest between 9 th and 13th rays, posterior rays approximately equal in height, but last 2 rays shorter; last ray about 0.4 times length of longest ray, attached to caudal peduncle by a membrane for about half its length; fin membranes continuous distally between spines and slightly incised between rays; membrane continuous between spinous and soft dorsal fins, attached to distal tip of terminal spine and to distal fourth of 1st soft ray. Anal fin slightly lower than dorsal fin; 2 soft and flexible spines shorter and closer together than soft rays; 2 nd spine longer than 1st one; 1 st soft ray 1.5 to 2.5 times length of 1 st spine; soft ray increasing in height posteriorly, but last 2 or 3 rays shortened; last anal ray attached only at its base to caudal peduncle by a membrane; fin membrane incised between rays, attached anteriorly to distal tip of ray and posteriorly to distal third of next ray. Caudal fin short and rounded, rather truncate in young specimens (less than $40 \mathrm{~mm}$ in S. L.), with $6 \sim 7+13+5 \sim 6$ rays; minimal hypural absent; epiural 1 or 2 ; fin membranes between lower 4 rays slightly incised. Pectoral fin short and rounded, with middle rays longest; lower 5 rays slightly thicker than upper ones (those in specimens from empty shell of barnacle thicker than those in specimens from small rock hole); fin membranes more deeply incised ventrally than dorsally. Pelvic fin inserted before pectoral fin origin, consisting of a short thin splintlike spine and 3 soft rays; of the latter, 2nd ray longest and 3rd ray shortest; membrane between 1st and 2nd ray deeply incised and between 2nd and 3rd rays slightly incised.

Color in life: Life color exhibited by this species variable; whitish, pale brown and reddish phases. All individuals barred pattern. Whitish phase commonest. Grand color of whitish phase specimens metalic white but antero-dorsal interspaces pale brown. When viewed from above, 8 to 10 blackish brown or black bands across the dorsal fin base; when viewed from side, these bands often continuous with next ones dorsally and reaching ventral contour of body or not; white specklings on body bands (more on anterior bands than posterior ones); pale brown antero-dorsal interspaces also with white specklings; the extensions of the bands slightly onto dorsal fin, frequently extend to half way onto dorsal spines and rays. Anterior spinous dorsal fin membranes 
dusky brown or pale brown, becoming posteriorly semitransparent; soft dorsal fin membranes semitransparent; spines with brown, blackish brown or reddish brown dashes; rays reddish with darker distal tips and more or less lighter submarginally; sometimes, brown, blackish brown or dark red spots on midway of rays forming a stripe. Anal fin membranes semitransparent without subterminal dusky band; rays reddish, darker posteriorly than anteriorly. Caudal fin membranes semitransparent; rays reddish. Pectoral fin membranes semitransparent; lower rays reddish, upper ones almost pale white. Pectoral fin base colored like body. Pelvic fin membranes more or less sooty; rays yellow. Head chocolate brown or blackish brown; cheek and opercle with thick pale specklings or blotches; jaws and isthmus also with pale specklings; frequently these specklings connected together so as to give the appearance to be barred dark and light; branchiostegals whitish basally, reddish distally; orbital cirri dusky tan; nuchal cirri chocolate brown to blackish brown.

In pale brown phase specimens, body bands brown; body bands and their pale brown interspaces with white specklings (more on anterior part than posterior part). All fins about the same as whitish phase. Head dusky tan to dusky brown; markings on head about the same condition as shown in whitish phase; orbital cirri dusky tan; nuchal cirri dusky brown.

In reddish phase specimens, body bands blackish, narrow interspaces slightly tinged with reddish purple. All fins colored about the same as whitish phase; occasionally fin membranes slightly tinged with yellow, rays uniformly bright red. Head reddish brown or reddish purple; markings on head about the same condition as shown in whitish phase; orbital cirri reddish brown or reddish purple; nuchal cirri somewhat dusky.

Etymology: lacuna means hole and incola means inhabitant. This species is named based on their habits.

\section{Neoclinus bryope (Jordan and Snyder) \\ (Japanese name: koke-ginpo)}

(Pl. I-G)

Zacalles bryope Jordan and Snyder, 1903; 448; Snyder, 1912: 447-448 (Zacalles misspelled); Jordan, Tanaka and Snyder, 1913: 380; Ui, 1929: 264; Schmidt, 1931: 146-147; Okada and Matsubara, 1938: 395; Okada, 1938: 258; Katayama, 1940: 24; Kamohara, 1950: 268; Tomiyama, 1951: 8-10; Fowler, $1958: 168$.

Calliblennius bryope Barbour, 1912: 187.

Zacal bryopeles Kuroda, 1931: 125.

Neoclinus bryope Hubbs, 1952: 52; Hubbs, 1953: 17-18; Matsubara, 1955: 736; Mori, 1956: 21 ; Kuroda, 1957: 5; Kamohara, 1958: 70; Kamohara, 1960: 14; Stephens, 1961 : 484-485; Honma, 1963: 21; Honma and Sugihara, 1963: 6; Kamohara, 1964: 91; Tomiyama, 1965: 336; Araga and Tanase, 1966: 86; Shiogaki and Dotsu, 1972: 1-8; Lindberg and Krasjukowa, 1975: 27; Masuda, Araga and Yoshino, 1975: 262.

Specimens examined: FAKU 48225, 1 male, $56.2 \mathrm{~mm}$; October 31, 1973; rocky reef of Toshima, at the mouth of Tanabe Bay, Wakayama Prefecture; about $2 \mathrm{~m}$ in depth. FAKU 48227, 1 male, $53.1 \mathrm{~mm}$; December 2, 1973; same locality as FAKU 
48225. FAKU 48388, 1 male, $48.5 \mathrm{~mm}$; August 21, 1973; same locality as FAKU 48225. FAKU 48437, 1 young, $36.4 \mathrm{~mm}$; July 12, 1973; rocky reef off northern beach of the laboratory; in a tide pool. FAKU 48438, 2 females, $41.1 \mathrm{~mm}$ and 45.1 mm; June 2, 1973; rocky reef of Tanjiri, at the mouth of Tanabe Bay; in a tide pool. FAKU 48521, 1 young, $36.3 \mathrm{~mm}$; April 15, 1975; rocky reef off northern beach of the laboratory; about $3 \mathrm{~m}$ in depth. FAKU 48933, 1 female, $51.2 \mathrm{~mm}$; April 29, 1975; same locality as FAKU 48521. FAKU 48936, 1 male, $42.0 \mathrm{~mm}$; April 15, 1975; same locality as FAKU 48521. FAKU 48945, 1 male, $46.4 \mathrm{~mm}$; June 1, 1975; same locality as FAKU 48521. FAKU, 489581 male, $54.2 \mathrm{~mm}$; May 18, 1975; same locality as FAKU 48521. FAKU 48961, 1 female, $50.9 \mathrm{~mm}$; July 9, 1975; same locality as FAKU 48225. FAKU 48966, 1 female, $45.3 \mathrm{~mm}$; August 1, 1975; same locality as FAKU 48521. FAKU 49371, 1 male and 1 female, $43.5 \mathrm{~mm}$ and $50.9 \mathrm{~mm}$; August 2, 1976; same locality as FAKU 48225. FAKU 49491, 1 male, $60.3 \mathrm{~mm}$; May 20, 1976; rocky reef of Tanjiri; about $3 \mathrm{~m}$ in depth. FAKU 49502, 1 male, $62.9 \mathrm{~mm}$; December 4, 1976; same locality as FAKU 49491. FAKU 49503, 1 male, $49.5 \mathrm{~mm}$; February 13, 1977; same locality as FAKU 48521. FAKU 49536, 4 males and 2 females, 38.0 $55.6 \mathrm{~mm}$; June 13, 1977; same locality as FAKU 48225. FAKU 49537, 1 male, 41.4 mm; June 13, 1977; same locality as FAKU 48225. FAKU 49538, 1 young, 1 male and 1 female, 21.0-49.2 mm; June 14, 1977; same locality as FAKU 48521. FAKU 49539, 3 males, 50.0-59.0 mm; June 15, 1977; rocky reef of Shisojima, at the mouth of Tanabe Bay; about $3 \mathrm{~m}$ in depth. FAKU 49542, 1 young and $1 \mathrm{male}, 31.3 \mathrm{~mm}$ and $49.7 \mathrm{~mm}$; June 18, 1977; same locality as FAKU 48521. FAKU 49543, 1 young and $1 \mathrm{male}, 26.7 \mathrm{~mm}$ and $49.2 \mathrm{~mm}$; June 19, 1977; same locality as FAKU 48521.

\section{Description}

Frequency distributions for each count are shown in Tables 2 to $5 . \quad$ Ranges and mean values of proportional measurements are shown in Table 6. Relative growth of some parts of body shown in Figs. 5 to 12 .

Body rather elongate, compressed, tapering from its deepest point (at pelvic insertion) to caudal peduncle. Caudal peduncle short and deep. Head relatively large; somewhat depressed, oval in cross-section posteriorly, somewhat compressed, toward tip of snout. Snout short and blunt. Eye anterior and dorsal; lens spherical. Interorbital area narrow and convex, at its narrowest point about equal to one-third to one-half length of orbit, with or without slightly raised fleshy marginal ridges. Right and left nasals separate, not articulated medially. Circumorbital bones 4, stout; lachrymal much larger than the other ones, bounded entire ventral border of eye; dermosphenotic not identifiable. Frontal with marginal ridge between orbit. Rest part of frontal and parietal slightly uneven. Nasal cirri 1 to 7 on posterior rim of anterior nostril; each cirrus thin with 1 to 3 tapered tips. Orbital cirri 3 or 4 (mostly 3 ), arranged in a row (Fig. 13, C), much branched; slender branches with tapered tips mostly subdivided (Fig. 13, C-a); generally Ist cirrus longest and most branched, especially in small specimens; 1 st cirrus 1 to 1.75 times length of orbit. Nuchal cirrus absent. Occipital region rather flattened, not swollen and rather smooth on surface. Upper margin of opercle united to body by thin membrane. Right and left opercular 
Table 6. Ranges and mean values of proportional measurement.

\begin{tabular}{|c|c|c|c|c|c|c|c|c|c|c|c|c|}
\hline & \multicolumn{4}{|c|}{ N. toshimaensis } & \multicolumn{4}{|c|}{ N. lacunicola } & \multicolumn{4}{|c|}{ N. bryope } \\
\hline & Mean & N. & Min. & Max. & Mean & $\mathrm{N}$. & Min. & Max. & Mean & N. & Min. & Max. \\
\hline Standard length (in mm) & 44.0 & 33 & 29.1 & 59.1 & 42.0 & 30 & 26.7 & 57.1 & 45.2 & 36 & 21.0 & 62.9 \\
\hline Total length & 1.141 & 33 & 1.104 & 1.177 & 1. 140 & 29 & 1. 118 & 1. 172 & 1.136 & 36 & 1.118 & 1. 179 \\
\hline Body depth & .160 & 33 & .140 & .171 & .145 & 29 & .124 & .162 & .155 & 35 & .141 & .187 \\
\hline Caudal peduncle depth & .073 & 33 & .065 & .097 & .070 & 30 & .064 & .085 & .071 & 36 & .062 & .078 \\
\hline Caudal peduncle length & .058 & 33 & .052 & .067 & .058 & 30 & .045 & .067 & .055 & 36 & .047 & .072 \\
\hline Predorsal length & .166 & 33 & .147 & .209 & .163 & 30 & .138 & .195 & .179 & 36 & .153 & .229 \\
\hline Preanal length & .425 & 32 & .405 & .460 & .417 & 30 & .391 & .443 & .428 & 36 & .411 & .445 \\
\hline Anal origin to pelvic insertion & .244 & 33 & .224 & .274 & .236 & 30 & .212 & .275 & .227 & 36 & .210 & .256 \\
\hline Head length & .212 & 33 & .187 & .234 & .211 & 30 & .177 & .244 & .236 & 36 & .215 & .290 \\
\hline Head width & .162 & 33 & .149 & .176 & .147 & 30 & .122 & .176 & .156 & 36 & .138 & .181 \\
\hline Snout length & .042 & 33 & .034 & .051 & .039 & 30 & .025 & .050 & .049 & 36 & .038 & .058 \\
\hline Postorbital length of head & .129 & 33 & .117 & .137 & .137 & 30 & .121 & .159 & .139 & 36 & .124 & .160 \\
\hline Orbit to angle of preopercle & .093 & 33 & .083 & .134 & .091 & 30 & .077 & .101 & .096 & 36 & .079 & .110 \\
\hline Orbital length & .052 & 33 & .041 & .065 & .050 & 30 & .039 & .067 & .057 & 36 & .045 & .081 \\
\hline Upper jaw length & .115 & 33 & .098 & .127 & .109 & 30 & .091 & .126 & .137 & 36 & .122 & .148 \\
\hline Dorsal fin base length & .829 & 33 & .790 & .855 & .835 & 30 & .797 & .872 & .800 & 36 & .757 & .843 \\
\hline Soft dorsal fin base length & .317 & 33 & .223 & .346 & .319 & 30 & .267 & .363 & .277 & 36 & .251 & .318 \\
\hline Anal fin base length & .544 & 33 & .510 & .574 & .549 & 30 & .524 & .569 & .544 & 36 & .501 & .567 \\
\hline First dorsal spine length & .068 & 33 & .051 & .095 & .056 & 30 & .039 & .098 & .086 & 35 & .063 & .114 \\
\hline Longest dorsal spine length & .094 & 33 & .080 & .115 & .092 & 30 & .074 & .129 & .103 & 36 & .074 & .147 \\
\hline Longest dorsal ray length & .102 & 33 & .080 & .124 & .108 & 30 & .093 & .132 & .101 & 36 & .085 & .122 \\
\hline First anal spine length & .039 & 33 & .023 & .071 & .035 & 29 & .022 & .049 & .038 & 35 & .029 & .049 \\
\hline First anal ray length & .067 & 32 & .053 & .079 & .065 & 29 & .047 & .079 & .063 & 35 & .051 & .086 \\
\hline Longest anal ray length & .081 & 33 & .068 & .101 & .084 & 30 & .075 & .096 & .080 & 36 & .063 & .100 \\
\hline Longest pectoral ray length & .141 & 33 & .113 & .168 & .137 & 30 & .114 & .172 & .140 & 36 & .121 & .181 \\
\hline Longest pelvic ray length & .104 & 33 & .079 & .130 & .093 & 30 & .077 & .114 & .117 & 36 & .085 & .157 \\
\hline
\end{tabular}


membranes broadly united each other free from isthmus. Branchiostegals 6. Gill rakers $8 \sim 10+10 \sim 15=19 \sim 24$ on first arch; those on upper limb short and pointed (last 1 to 3 rudimentary); those on lower limb thin and slender. Lips broad and fleshy, with free margins; free margin of upper lip continuous across the midline, that of lower lip not continuous. Upper jaw reaching beyond hind margin of eye, a distance about equal to orbit length. Seven to 9 large, slightly recurved, somewhat incisorlike teeth along anterior border of each premaxillary; these teeth becoming smaller posteriorly; a band of small villiform teeth medial to these; 7 to 19 moderatesized teeth extending along ramus in a single row to half the distance to angle of jaws. Seven to 12 moderate-sized teeth with pointed tips in a single row on palatine; teeth increasing in length to $3 \mathrm{rd}$ one, then becoming smaller posteriorly. Five moderatesized teeth in an anterior crescentic row on vomer; center tooth largest. Six to 10 large teeth along anterior border of each mandible; anterior ones somewhat incisorlike, slightly recurved and posterior 2 or 3 ones caninlike; a band of small villiform teeth medial to these (less than those on premaxillary in number, slightly larger in size); those on posterior margin of these band somewhat larger; 8 to 15 moderate-sized teeth extending along ramus in a single row to angle. Lateral line on head complete, canals of (F1) and (F2) elongate. Typical pore patterns and lateral line canal on head illustrated in Fig. 3, C1 and C2. Cephalic sensory pores small and relatively many in number. Pore counts of each series are shown in Table 4. Counts of SO series including those of (F1) and (F2) series.

Raised, distinct anterior part of lateral line on body running posteriorly from upper margin of opercle to a point below 8th to 13th dorsal spine, at which point slightly turns downward or not; 16 to 26 scales in this anterior part, each with a pore above and below the canal, except for last 1 to 3 scales with a single median pore. Behind this anterior part, canal becoming soon invisible. Head, belly and all fins naked. An area above lateral line and in front of the 7 th dorsal spine also scaleless (Fig. 14, C). Comparatively large cycloid scales with no radii on their posterior magins, embedded, very closely spaced or slightly imbricated; one somewhat larger scale in each somite on midline of body (Fig. 14, G). Urogenital sinus sexially dimorphic. In male, urogenital sinus opening at the tip of a cone just behind anus; surface of cone smooth; anus surrounded by a wall with radial folds. In female, urogenital sinus opening at the tip of a tubular process and lying close to anus; anterior side of urogenital tube forming posterior wall of anal cavity; urgoenital tube and anus with folds and papilla.

Dorsal fin originating on nape, about half way between posterior margins of opercle and of eye. Spinous dorsal fin relatively high; in male, spines increasing in height to $3 \mathrm{rd} \sim 6$ th spine, then decreasing in height to 7 th $\sim 10$ th spine, posterior spines approximately equal in height, but last one noticeably shorter; in female, spines, except for last one which is noticeably shorter, subequal or middle ones slightly shorter. Dorsal spines, especially anterior ones, soft and flexible, except for last one which is stiff; a thin, narrow membrane along anterior edge of 1st dorsal spine. Usually soft dorsal fin slightly higher than spinous dorsal fin; rays increasing in height gradually to 7 th $\sim 10$ th ray, posterior rays approximately equal in height, but last 2 rays shorter; last ray about equal to one-half the length of longest ray, attached to caudal peduncle 
by a membrane in various extent (in one extreme, only at its base, in another extreme, membrane extends between distal tip of it and posterior end of caudal peduncle); fin membranes continuous distally between spines and slightly incised between rays; membrane continuous between spinous and soft dorsal fins, attached to distal tip of the last spine but one and to distal fouth of lst soft ray; i.e., terminal spine not reaching edge of membrane. Anal fin lower than dorsal fin; 2 soft and flexible spines shorter and closer together than soft ray; 2nd spine longer than 1st spine; 1st anal soft ray 1.5 to 2 times length of lst spine; soft ray increasing in height posteriorly, but last 2 or 3 rays shortened; last ray about equal to two-thirds length of 1st soft ray; last anal ray attached only at its base to caudal peduncle by a membrane; fin membranes between rays incised, attached anteriorly to distal tip of ray and posteriorly to distal third of ray. Caudal fin short and rounded, rather truncate in young specimens (less than $40 \mathrm{~mm}$ in S. L.), with $5 \sim 7+13+5 \sim 7$ rays; minimal hypural present; epiural 1 to 3 ; fin membranes between rays slightly incised; those between lower 4 rays somewhat deeper incised than those between upper rays. Pectoral fin short and rounded, with middle rays longest; lower 3 to 4 rays thicker than upper ones; fin membranes more deeply incised ventrally than dorsally. Pelvic fin inserted before pectoral origin, consisting of a short thin splintlike spine and 3 soft rays; of the latter, 2nd ray longest and 3rd ray shortest; membrane between 1 st and 2 nd rays deeply incised and that between 2 nd and 3 rd rays slightly incised.

Color in life: Life color patterns exhibited by this species varies from almost plain to strongly barred. In typical barred pattern specimens, ground color of upper half of body light brown and lower half whitish; when viewed from above, 7 to 11 brown or dark brown short bands across the dorsal base; when viewed from side, besides these short bands, 8 to 11 brown or dark brown bands and 7 to 10 less distinct ones, which are broadest near the middle, narrow or pointed below and reach ventral contour of body or not; the extentions of the body bands slightly onto dorsal fin or not. Dorsal fin membranes between spines dusky brown or sooty, except for near the base where are pale orange or semitransparent; sometimes, middle part of these membranes, semitransparent to form a stripe; a black ocellus margined with light brown, in membrane between the first 2 spines; membranes between rays semitransparent; rays reddish brown, mottled with white so as to give the barred appearance. Anal fin membranes semitransparent with a subterminal dusky band; in female and in young, sometimes this subterminal dusky band incomplete; rays pale whitish. Caudal fin membranes semitransparent; rays reddish brown mottled with white so as to give the barred appearance. Pectoral fin membranes semitransparent; rays pale whitish; pectoral fin base with white specklings and 1 or 2 black spots. Pelvic fin membranes more or less sooty; rays white, yellow or dusky brown. Head light tan to blackish brown with black spots; in addition to these black spots, cheek, opercle, lips and isthmus with white spots; orbital cirri colored like head with whitish tips.

In plain pattern specimens, body tan to pale brown with trace of bands, upper half slightly darker than lower half. All fins about the same coloration as barred pattern specimens. Head tan to dusky brown; only opercle and near the angle of jaws 
with black spots; white spots on cheek, opercle, lips and isthmus relatively few and obscure.

\section{Habitat of Three Japanese Species of Neoclinus}

Three Japanese species of Neoclinus inhabit in rocky reef around the Seto Marine Biological Laboratory. Between 18 May and 1 July, 1977, observations were made on three species of Neoclinus at 11 stations in the inshore waters around the laboratory (Fig. 1) during day time. Periods of each observation lasted between 1 hour and 2 hours. The study area is warm temperate, washed by a branch of Kuroshio Current and has a rich fish fauna (Araga and Tanase, 1966). The water temperatures rise up nearly $30^{\circ} \mathrm{C}$ in mid-summer and fall down to about $12^{\circ} \mathrm{C}$ in mid-winter.

The numbers of each species observed at each station are shown in Table 7 . As the observation efforts and areas were not constant among stations, the numbers of each species are not comparable among them. Outlines of each station are shown in Table 8 .

Based on the degree of "exposure", 11 stations fall into two major groups. Namely, Sts. A, B, C, D, E and F are moderately exposed coasts, while Sts. G, H, I, J and $\mathrm{K}$ are very exposed coasts. The very exposed stations are characterized by settlement of a sessile organism, Balanus tintinnabulum volcano.

Neoclinus toshimaensis occurred in Sts. G, H, I. J and K, which are characterized as upper subtidal zone of very exposed rocky shore in depths ranging from 0.5 to $4 \mathrm{~m}$ below the mean low water level (Fig. 15). This species dominated in St. I (Table 7), where wave action is the strongest and always affected by turbulence. All individuals of this species observed occupied empty shell of $B$. tintinnabulum volcano and were not seen to emerge completely from their shells.

Neoclinus lacunicola occurred in Sts. B, C, D, H and J, namely, in upper subtidal zone of both moderately exposed and very exposed rocky shores in depths ranging from 0.5 to $4 \mathrm{~m}$ below mean low water level (Fig. 15). In Sts. B, C and D, all individuals of this species observed occupied perhaps burrowed by bivalves and were not seen to emerge completely from their holes. Although small rock holes were abundant in St. B where flourish of a seaweed, Ecklonia kurome was seen, fishes of this species and $N$. bryope were not seen so often there. In Sts. C and D, where flourish of the seaweed was not seen, small rock holes were occupied by fishes of this species and $N$. bryope at fairly high rate. In Sts. $\mathrm{H}$ and $\mathrm{J}$ which are vertical or somewhat overhanged rocky faces

Table 7. Number of each species observed at each station

\begin{tabular}{|c|c|c|c|c|c|c|c|c|c|c|c|}
\hline \multirow{2}{*}{ Species } & \multicolumn{11}{|c|}{ Station } \\
\hline & A & B & $\mathrm{G}$ & $\mathrm{D}$ & $\mathrm{E}$ & $\mathrm{F}$ & $\mathrm{G}$ & $\mathrm{H}$ & I & $\mathrm{J}$ & K \\
\hline N. toshimaensis & - & - & - & - & - & 一 & 13 & 13 & 35 & 3 & 5 \\
\hline N. lacunicola & - & 13 & 15 & 20 & - & - & - & 7 & - & 6 & - \\
\hline$N$. bryope & 25 & 4 & 9 & 8 & 5 & 8 & 12 & 7 & 4 & 1 & 7 \\
\hline
\end{tabular}


Table 8. Outlines of observed stations. ME: moderately exposed; VE: very exposed. Depth is taken at mean low tide

\begin{tabular}{|c|c|c|c|c|}
\hline Station & Exposure & Depth & Structural Components & $\begin{array}{l}\text { Conspicuous Sessile } \\
\text { Organisms }\end{array}$ \\
\hline A & $\mathbf{M E}$ & Intertidal & $\begin{array}{l}\text { Shallow ditch-like tide pools } \\
(5-10 \mathrm{~cm} \text { in depth) which have } \\
\text { fine gravels on bottom. }\end{array}$ & \\
\hline B & ME & $1-8 \mathrm{~m}$ & $\begin{array}{l}\text { Flat, cliff, large boulders }(1-3 \mathrm{~m} \\
\text { in diameter }) \text {. }\end{array}$ & Ecklonia kurome \\
\hline C & $\mathbf{M E}$ & $0-4 \mathrm{~m}$ & $\begin{array}{l}\text { Flat, cliff, slope, large boulders } \\
\text { ( } 1-3 \mathrm{~m} \text { in diameter }) \text {. }\end{array}$ & $\begin{array}{l}\text { Anthocidaris crassispina } \\
\text { Echinometra mathaei }\end{array}$ \\
\hline $\mathrm{D}$ & ME & $0-5 \mathrm{~m}$ & $\begin{array}{l}\text { Flat, cliff, large boulders }(1-3 \mathrm{~m} \\
\text { in diameter }) \text {. }\end{array}$ & $\begin{array}{l}\text { Anthocidaris crassispina } \\
\text { Echinometra mathaei }\end{array}$ \\
\hline $\mathrm{E}$ & ME & $\begin{array}{l}\text { Interdial } \\
-3 \mathrm{~m}\end{array}$ & $\begin{array}{l}\text { Flat, gully, large boulders (1-3 m } \\
\text { in diameter). }\end{array}$ & $\begin{array}{l}\text { Anthocidaris crassispina } \\
\text { Echinometra mathaei }\end{array}$ \\
\hline $\mathrm{F}$ & ME & $4-8 \mathrm{~m}$ & Flat, cliff. & $\begin{array}{l}\text { Diadema setosum } \\
\text { Balanus tintinnabulum } \\
\text { rosa }\end{array}$ \\
\hline G & VE & $0 \multimap 5 \mathrm{~m}$ & Slope. & $\begin{array}{l}\text { Balanus tintinnabulum } \\
\text { volcano } \\
\text { Echinothrix calamaris }\end{array}$ \\
\hline $\mathrm{H}$ & VE & $0-5 \mathrm{~m}$ & Cliff. & $\begin{array}{l}\text { Balanus tintinnabulum } \\
\text { volcano } \\
\text { Sponges } \\
\text { Crustose clacarious } \\
\text { algea }\end{array}$ \\
\hline I & VE & $0-3 \mathrm{~m}$ & Flat, slope, stack. & $\begin{array}{l}\text { Sargassum duplicatum } \\
\text { Amphiroa dilatata } \\
\text { Dictyota dichotoma } \\
\text { Echinostrephus } \\
\text { aciculatus }\end{array}$ \\
\hline $\mathbf{J}$ & VE & $0-3 \mathrm{~m}$ & Cliff. & $\begin{array}{l}\text { Balanus tintinnabulum } \\
\text { volcano } \\
\text { Sponges } \\
\text { Crustose calcarious } \\
\text { algea }\end{array}$ \\
\hline $\mathrm{K}$ & VE & $0-3 \mathrm{~m}$ & Flat, slope, pot holes. & $\begin{array}{l}\text { Balanus tintinnabulum } \\
\text { volcano } \\
\text { Corallina pilulifera }\end{array}$ \\
\hline
\end{tabular}

covered with sponges, crustose calcarious algae and patches of $B$. tintinnabulum volcano, all individuals of this species occupied empty shells of $B$. tintinnabulum volcano and were not seen to emerge completely from their shells. Individuals of $B$. tintinnabulum volcano on the cliff of these two stations settled closer together and were more slender than those on slopes and flats. In the cliffed rocky faces like Sts. $\mathrm{H}$ and $\mathrm{J}$ as well as in areas between large boulders in moderately exposed shore, waves become laminar-flow rather than turbulence which is seen on the slopes and flats.

Neoclinus bryope occurred in all stations. Of the three species, only $N$. bryope was found in Sts. A, E and F. In any other stations, this species did not dominate to the other two species (Table 7). In St. A, young of this species (25 to $40 \mathrm{~mm}$ in S. L.) were found in shallow ditch-like tide pools (5 to $10 \mathrm{~cm}$ in depths) where they hid themselves under and among fine gravels or broken pieces of shells. Other fishes observed in these tide pools were Tripterygion etheostoma, Omobranchus loxozonus, Istiblen- 
nius enosimae, Chasmichthys dolichognathus, Eviota abax and young of Girella punctata. In St. E which is the most sheltered area of all and small rock holes are scarce, only 5 individuals of this species were observed in small rock holes. One of them occupied a hole in intertidal zone. St. F is a submerged rocky reef without flourish of sea weeds, in depths ranging from 4 to $8 \mathrm{~m}$ at low tide. Five individuals of this species were found in small rock holes, two were found in empty shells of Balanus tintinnabulum rosa and one was wandering on rocky substrate. In Sts. B, G and D, fishes of $N$. bryope were observed in small rock holes. In St. C, however, 2 individuals of $N$. bryope were wandering on rocky substrate free from holes. In Sts. G, H, I, J and $\mathrm{K}$, all individuals of this species were found in empty shells of $B$. tintinnabulum volcano and were not seen to emerge completely from their shells.

From the result of observation described above, it may be concluded that $N$. toshimaensis prefers turbulent areas in upper subtidal zone and that $N$. lacunicola prefers areas affected by laminar-flow in upper subtidal zone. However, N. bryope was observed to occur from moderately exposed to very exposed rocky shores and from intertidal to a depth of about $8 \mathrm{~m}$ below mean low water level. It is noticeable that $N$. bryope is more widely distributed than the other two species in both the extent of exposure and the range of depths (Fig. 15).

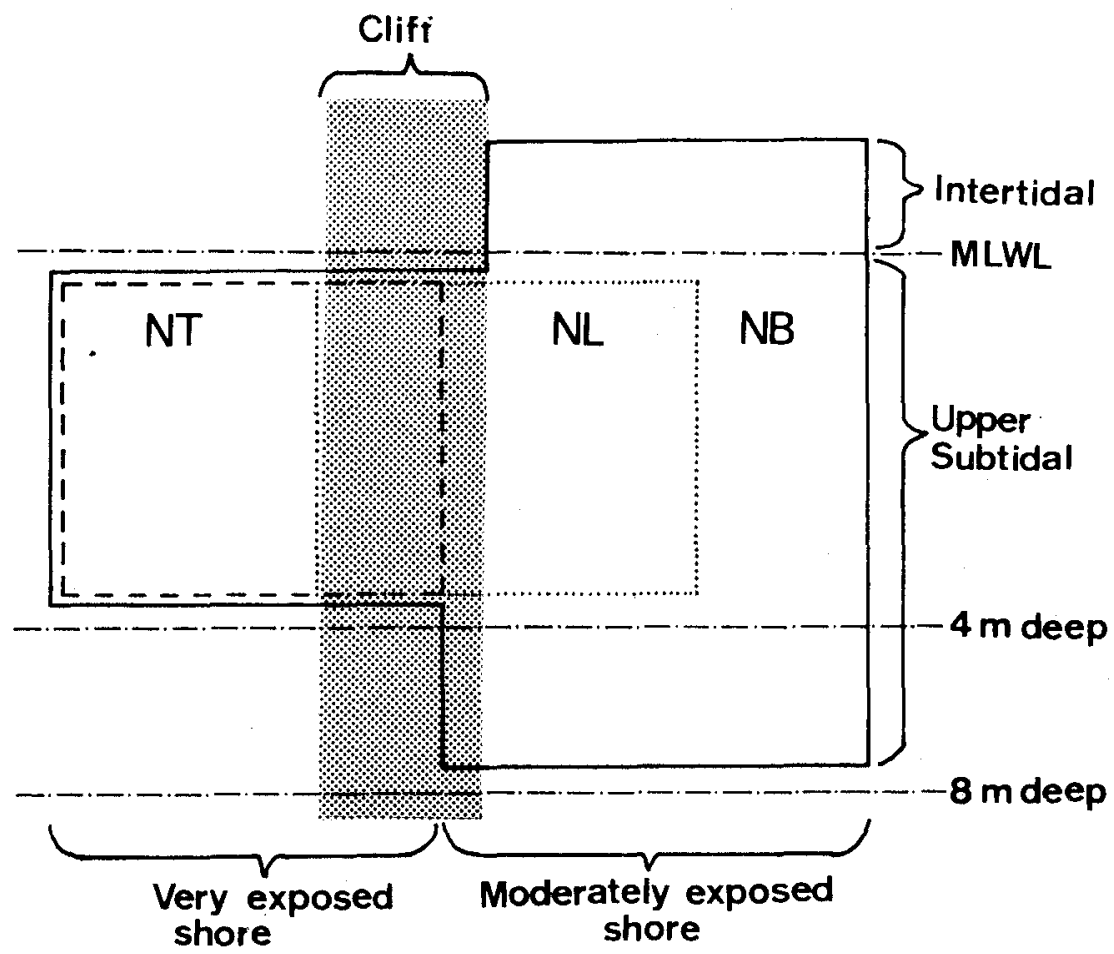

Fig. 15. Schematic illustration of habitat of three Japanese species of Neoclinus. An area enclosed by broken line shows habitat of $N$. toshimaensis (NT); an area enclosed by dotted line shows habitat of $N$. lacunicola (NL); an area enclosed by solid line shows habitat of $N$. bryope (NB). Dotted area shows cliffed rocky face. MLWL: mean low water level. 
The significant differences could not be observed on the behavior of three species in small rock holes or barnacle etsts. The behavior of them is similar to that of Mccoskerichthys sandae described by Rosenblatt and Stephens (1978). They protrude their heads from the holes or the shells (Pl. II-A) and sometimes snap at certain zooplanktons or drifting particles by short darts forward to one-half the body length or more (Pl. II-B). When a stick is approached to them, at first they draw their heads into their holes or shells, and then if further approach is made, they never leave there, but make a threat against the stick by a wide gaping of the mouth (Pl. II-G) which is not followed by an attack.

$N$. toshimaensis and $N$. lacunicola were always seen in their holes or shells. On the other hand, some individuals of $N$. bryope were wandering on rocky substrates, although most of this species are inhabitants of holes or shells. In the case of young $N$. bryope, some individuals hid themselves under and among fine gravels or broken pieces of shells in tide pools. Furthermore, in the intertidal of Hatakejima Island located at the middle part of Tanabe Bay (Fig. 1), Araga (personal communication) found that some adults of $N$. bryope lived under a rock in a shallow tide pool. From these facts, $N$. bryope is more facultative in utilization of holes or shells as compared to the other two species.

In moderately exposed stations, $N$. lacunicola and $N$. bryope coexisted in Sts. B, C and $\mathrm{D}$ where all individuals of $N$. lacunicola and most of $N$. bryope lived in small rock holes. A difference was noticed in preference of hole between these two species. Of 48 individuals of $N$. lacunicola observed there, 30 were found in holes on vertical wall of the rock and the rest 18 were found in holes on upper surface of the rock. However, of 20 individuals of $N$. bryope observed in holes there, only 2 were found in holes on vertical wall of the rock and the rest 18 were found in holes on upper surface of the rock. All individuals of $N$. lacunicola found in holes on vertical wall of the rock have whitish phase in body coloration, while those found in holes on upper surface of the rock have pale brown phase. All individuals of $N$. bryope observed in moderately exposed stations have barred pattern. There is a tendency that females are darker than males in N. bryope.

In very exposed stations, two species, $N$. toshimaensis and $N$. bryope coexisted in Sts. G, I and $K$, and three species coexisted in cliffed stations of both J and $H$. All individuals of these three species were found in empty shells of $B$. tintinnabulum volcano in all these stations. $N$. lacunicola inhabited only on the cliff, occupying the empty shells. No differences were noticed in utilization of empty shells of $B$. tintinnabulum volcano between the other two species, although it seems likely that $N$. toshimaensis prefers the most turbulent areas and $N$. bryope does not prefer such areas. All individuals of $N$. toshimaensis and of $N$. lacunicola observed in cliffed Sts. $\mathrm{H}$ and $\mathrm{J}$ have reddish phase and external appearances of these two species in their reddish phases are closely resemble each other. The life color of $N$. toshimaensis observed in empty shells on slopes and flats is much variable in the color phases and varies the pattern almost plain to strongly barred. The pattern of $N$. bryope observed in very exposed stations varies from almost plain to strongly barred. These color phases and patterns do not change instan- 
taneously but changes take place within 2 or 3 days in captivity.

In moderately exposed stations, other fishes observed in small rock holes were a tiny gobiid fish Eviota abax. They were rarely found in holes on upper surface of the rock.

In very exposed stations, other fishes observed in empty shells of $B$. tintinnabulum volcano on upper subtidal rocky reef were Pictiblennius yatabei, Mimoblennius atrocinctus, young of Cirripectes sebae and Abudefduf lencozonus. P. yatabei were common but fewer than fishes of Neoclinus. The latter 3 species were rarely found in empty shells of $B$. tintinnabulum volcano. $\quad P$. yatabei uses empty shells of $B$. tintinnabulum volcano for breeding sites where the males guard the deposited egg masses. In the lower intertidal zone, empty shells of $B$. tintinnabulum volcano are used for breeding sites by Scartella cristata, Entomacrodus stellifer, Entomacrodus caudofasciatus, Entomacrodus striatus and Entomacrodus thalassinus. Males of these fishes guard the deposited egg masses. In very exposed shore, the former 2 species are abundant in intertidal zone. Since the fishes of Neoclinus do not use the empty shells of $B$. tintinnabulum volcano in these zone, there is no competition for empty shells of $B$. tintinnabulum volcano between fishes of Neoclinus and the other fishes mentioned above in intertidal zone.

\section{Discussion}

The finding of $N$. toshimaensis and $N$. lacunicola brings the number of species from four to six in the genus Neoclinus. Hubbs (1953) distinguished N. bryope from the other three Californian species of the genus as follows:

"It $(N$. bryope $)$ is probably most closely related to $N$. stephensae but is readily separable from that species by the presence of an ocellus on the membrane between the first two dorsal spines, by the absence of a nuchal cirrus, and by usually having 14 instead of 15 pectoral rays. Specimens of both stephensae and bryope can be separated from blanchardi and uninotatus by the smaller size at maturity (under 100 millimeters standard length as opposed to over 100 millimeters standard length), by the more numerous gill rakers (about 20 instead of about 12), and by the smaller size of the eye."

My specimens of both $N$. toshimaensis and $N$. lacunicola do not exceed $60 \mathrm{~mm}$ in standard length and have about 15 gill rakers, and their orbit lengths are slightly smaller than that of $N$. bryope (Fig. 8). These characteristics distinguish them from N. blanchardi and $N$. uninotatus. Both $N$. toshimaensis and $N$. lacunicola are more closely related to $N$. stephensae than $N$. bryope, in respect of the absence of an ocellus on the membrane between the first two dorsal spines and the presence of a nuchal cirrus. However, $N$. toshimaensis and $N$. lacunicola are easily distinguished from $N$. stephensae by the number of gill rakers (about 15 instead of about 20), number of anterior lateral line scales (less than 15 as opposed to about 20) and number of orbital cirri (more than 6 as opposed to 4). $N$. toshimaensis and $N$. lacunicola are closely related each other, but former is separable from the latter by the arrangement and shape of orbital cirri (Fig. 16), number of orbital cirri $(9 \sim 11$ in the former and $6 \sim 7$ in the latter), number of total vertebrae 
(more than 49 in the former and less than 48 in the latter), number of dorsal fin elements (41 to 45 , mostly 44 in the former and 38 to 42 , mostly 41 in the latter) and number of anal fin elements ( 30 to 33 , mostly 31 or 32 in the former and 28 to 31 , mostly 29 or 30 in the latter).

Some discrepancies are noticed in meristic characters of $N$. bryope between my result and Hubbs' description (1953). The modal number of pectoral fin ray counts is 13 instead of 14, that of dorsal fin spine counts is 24 to 25 instead of 25 to 26 , and that of anal fin ray counts is 28 to 29 instead of 29 to 30 . Specimens examined by Hubbs were from Misaki, Japan (about $35^{\circ} 8^{\prime} \mathrm{N}$ and $139^{\circ} 36^{\prime} \mathrm{E}$ ) where is colder than Tanabe Bay (about $33^{\circ} 41^{\prime} \mathrm{N}$ and $135^{\circ} 20^{\prime} \mathrm{E}$ ) in winter. These differences mentioned above, therefore, may be geographical variations of the species. Stephens (1961) reported the two specimens of $N$. bryope from Okinawa, which have 13 pectoral rays, 24 and 25 dorsal spines and 28 and 29 anal rays. He also recognized a difference in the degree of squamation between the specimens from Okinawa and those from northern Japan. Namely, in the Okinawan specimens, scales are embedded and are extremely difficult to observe, while, in the latter specimens, scales are identical in shape and size in all locations on the body. As compared with specimens with visible scales from Misaki*, the specimens from Tanabe Bay have extremely thin delicate embedded scales which are difficult to observe. It seems likely that there is no difference between the Okinawan specimens and the specimens from Tanabe Bay. On the problem of geographical variation of $N$. bryope, further studies are desirable.

Relative growth of 25 selected parts in the three Japanese species of Neoclinus is as follows. In all three species, the proportion of predorsal length (Fig. 6), head length (Fig. 7), orbit length (Fig. 8), longest pectoral ray length (Fig. 11) and longest pelvic ray length (Fig. 12) decrease as they grow. The proportion of dorsal fin base length (Fig. 10) increases as they grow up to $40 \mathrm{~mm}$ in standard length and then become constant over $40 \mathrm{~mm}$ in both $N$. toshimaensis and $N$. lacunicola. The proportion of this part in $N$. bryope (Fig. 10) increases as they grow. The proportion of upper jaw length in $N$. bryope is constant or slightly increases as they grow, whereas that in $N$. toshimaensis and $N$. lacunicola decreases as they grow (Fig. 9). As a whole, in the growth characteristics, the relation between $N$. toshimaensis and $N$. lacunicola is closer than that between $N$. bryope and $N$. toshimaensis or $N$. lacunicola. In all of three species, the proportion of body depth (Fig. 5) and lengths of the rest parts have not any significant tendency with growth. The proportion of body depth in $N$. lacunicola is slightly smaller than that in the other two species. This means that $N$. lacunicola is more slender than the other two species. The number of vertebrae of $N$. lacunicola and $N$. bryope are fewer than that of $N$. toshimaensis (Table 3). In contrast with the case of chaenopsids reported by Stephens (1963), it is curious that the number of vertebrae and the degree of body elongation are not correlated in three Japanese species of Neoclinus.

Stephens (1963) stated that the Chaenopsidae are certainly closely related to the Clinidae, and probably arose from a line closely related to Neoclinus. Rosenblatt and Stephens (1978) reported that Neoclinus has a distinct dermosphenotic not present in

*ZMUT (Zoological Museum, University of Tokyo) 28642-63, 28896-900, 38931-37 and 38995. 
Mccoskerichthys or other chaenopsids. It was not found, however, in the three Japanese species of Neoclinus in this study. Rosenblatt and Stephens (1978) might not examine Japanese species but Californian species of this genus. The possession of the dermosphenotic may suggest that three Japanese species are more closely related to the chaenopsids than Californian species are. As compared with $N$. bryope, both $N$. toshimaensis and $N$. lacunicola have reduced lateral line (Table 5), reduced cephalic sensory pore (Table 4 and Fig. 3) and reduced squamation (Fig. 14). In the chaenopsids, the lateral line is absent, most of the cephalic sensory pores are simple, and the body is scaleless (Rosenblatt and Stephens, 1978). Therefore, the latter two species are more closely related to the chaenopsids.

Stephens (1963) reported that the nasals are separated in Neoclinus and the majority of the Clinidae and are united medially each other in the Protemblemaria to Acanthemblemaria line* of chaenopsids. Certainly, in $N$. bryope, right and left nasals are separated, but in $N$. toshimaensis, right and left nasals are articulated medially each other. In this respect, it seems likely that $N$. toshimaensis has the affinity with the Protemblemaria to Acanthemblemaria line of chaenopsids. In $N$. lacunicola, right and left nasals are separated or articulated medially each other. This fact indicate that $N$. lacunicola may occupy an intermediate position between $N$. toshimaensis and $N$. bryope. This is also true in the number of precaudal vertebrae (13 to 14 , mostly 14 in $N$. toshimaensis, 12 to 13, mostly 13 in $N$. lacunicola, 12 in $N$. bryope). However, N. toshimaensis and $N$. lacunicola have not any minimal hypural, whereas $N$. bryope has a minimal hypural. For this reason and reasons mentioned earlier (the condition of lateral line, cephalic sensory pores and squamation; presence or absence of nuchal cirri and ocellus on the membrane between the first two dorsal spines; growth characteristics), N. lacunicola is more closely related to $N$. toshimaensis than to $N$. bryope, although meristic characters of $N$. lacunicola are closer to that of $N$. bryope rather than to that of $N$. toshimaensis (Table 2 and 3). Furthermore, in the cliffed rocky face of very exposed shore where $N$. toshimaensis and $N$. lacunicola coexist, both two species have reddish phase in body coloration and their external appearance are closely resemble each other. This also seems to indicate the close relationship between these two species. On the other hand, there is a fairly large gap between $N$. lacunicola and $N$. bryope.

All three Japanese species of Neoclinus inhabit in exposed rocky shore of Tanabe Bay. Of the three species, $N$. bryope has the most facultative habitat preference. It occurs from moderately exposed to very exposed rocky shores and from intertidal to a depth of about $8 \mathrm{~m}$ below mean low water level (Fig. 15). On the other hand, $N$. toshimaensis and $N$. lacunicola share their habitat within the habitat of $N$. bryope (Fig. 15), although in the areas where $N$. bryope and $N$. toshimaensis or $N$. lacunicola coexist, there is a certain extent of habitat segregation between $N$. bryope and the latter two species (i.e., in moderately exposed shore, $N$. lacunicola prefers the hole on vertical wall of the rock, whereas $N$. bryope prefers the hole on upper surface of the rock; in very exposed

*Stephens (1963) recognized an early split in chaenopsid phylogeny. Namely, two lines have developed, the Pseudemblemaria (synonymized with Emblemariopsis in Stephens' 1970 classification) to Chaenopsis line and the Protemblemaria to Acanthemblemaria line. 
shore, $N$. toshimaensis prefers the most turbulent areas and $N$. bryope does not prefer such areas). Three species coexist only on the cliffed rocky face of very exposed shore (Fig. 15). N. bryope is the facultative inhabitants of holes or barnacle tests, whereas both $N$. toshimaensis and $N$. lacunicola are the obligate inhabitants of holes or barnacle tests. This fact is correlated with some morphological characters. Namely, both $N$. toshimaensis and $N$. lacunicola have reduced lateral line and reduced squamation. Gosline (1959) stated that both reduction of lateral line and reduction of scales might be considered an ecological specialization to the tubiculous way of life. From the facts mentioned above, of the three species, $N$. bryope is the most generalized form in both morphological and ecological characteristics. On the other hand, both $N$. toshimaensis and $N$. lacunicola have increasing reliance on the tubiculous habit, more restricted habitat preference and closer relationship to the chaenopsids. These two species are very closely related each other and seem to be derived from the common ancestoral form rather recently. $N$. toshimaensis seems to have specialized to turbulent areas, and $N$. lacunicola to the areas affected by laminar-flow.

The genus Neoclinus now contains three Japanese species and three Californian species. The distribution pattern of this genus is a case of so-called "Japan-Oregon element". Similar distribution is known for the family Embiotocidae (Tarp, 1952). As mentioned by Hubbs $(1952,1953)$, this genus probably originated not in Japanese waters, but in California or in the New World tropics. Because the family Clinidae is considered to originate in the New World tropics (Hubbs, 1952) and other than the fishes of Neoclinus, only two clinid species, Petraites flammeus and Petraites roseus are known from Japan. Futhermore, another related family Chaenopsidae is restricted to the New World tropics. Hubbs (1953) estimated that N. bryope emigrated to Japan through the Aleutians during an intergalcial period. As both $N$. toshimaensis and $N$. lacunicola have increasing relaiance on tubiculous habit and more restricted habitat preference, they seem to have the relatively limited ability of expansion of distribution. These two species seem to be unable to emigrate over the long distance between California and Japan, after they got the limited ability of expansion of distribution. So it could be difficult to consider that all three species differentiated in California or the New World tropics and then emigrated to Japan. Bearing in mind that $N$. bryope is the most generalized form and that $N$. toshimaensis and $N$. lacunicola seem to be derived from the common ancestral form rather recently as well as the respects mentioned above, two possible cases could be estimated. 1) $N$. bryope or an ancestral form akin to it emigrated to Japan and then differentiated to the present three species in Japan. 2) N. bryope or its ancestral form and the common ancestral form of the other two species emigarted to Japan and then present three species appeared in Japan.

My observations on blenioid fishes in Okinawa (March, 1973 and October, 1974) and Ogasawara (April, 1974) could not find any fishes of the genus Neoclinus, though two specimens of $N$. bryope were reported from Okinawa (Stephens, 1961). In Tanabe Bay, there are relatively few competitors with fishes of Neoclinus for the holes or barnacle tests. On the contrary, in Okinawa and Ogasawara, the holes and barnacle tests available for fishes of Neoclinus are occupied by many blenniids: Aspidontus taeniatus, 
Aspidonus dussumieri, Plagiotremus rhinorhynchos, Ecsenius bicolor, Escenius lineatus, Ecsenius oculus, Stanulus talboti, Salarias luctuosus, Glyptoparus delicatulus, Nannosalarias nativitatus and Mimoblennius atrocinctus. Both $N$. toshimaensis and $N$. lacunicola are obligate inhabitants of holes or barnacle tests and have more restricted habitat preference. Absence of these two species in Okinawa and Ogasawara suggests the effect of habitat preference and competition. $N$. bryope has more facultative habitat preference and is more facultative inhabitants of holes or barnacle tests than the other two species of Neoclinus. Owing to this fact, only $N$. bryope might be able to extend to tropics (Okinawa).

\section{Acknowledgements}

I am grateful to Professor Tamotsu Iwai of Kyoto University, Mr. Chuichi Araga of the Seto Marine Biological Laboratory, Kyoto University, Mr. Izumi Nakamura of the Fisheries Research Station, Kyoto University and Mr. Yasunobu Yanagisawa of Ehime University for their helpful suggestions and critical reading of the manuscript. Thanks are also due to Mr. Mutsumi Nishida, Mr. Tetsuji Nakabo and Mr. Hiroshi Ueda of our laboratory for their encouragement and helpful advice. I am grateful to Mr. Tetsuo Kuwamura of the Seto Marine Biological Laboratory for providing some specimens of $N$. bryope from Tanabe Bay. Thanks are also due to Dr. Yoshiaki Tominaga of the Zoological Museum, University of Tokyo for giving me a chance to examine some specimens of $N$. bryope from Misaki. This study was financially supported in part by the fund of the Ito Gyogaku Shinko Zaidan.

\section{Summary}

1. Two new species, $N$. toshimaensis and $N$. lacunicola were described and $N$. bryope was redescribed based on the specimens from Tanabe Bay. The key to these three Japanese species was devised.

2. These two new species were briefly compared with the other four species of the genus.

3. Some differences are noticed in meristic characters of $N$. bryope between my result and description by Hubbs (1953). These differences may be geographical variations of the species.

4. Relative growth was studied in the three Japanese species of Neoclinus. In the growth characteristics, the relation between $N$. toshimaensis and $N$. lacunicola is closer than that between $N$. bryope and $N$. toshimaensis or $N$. lacunicola.

5. Some morphological characters of the three Japanese species of Neoclinus were compared. $N$. toshimaensis and $N$. lacunicola are closely related each other and more closely related to the chacnopsid than $N$. bryope are.

6. The habitats of the three Japanese species of Neoclinus was studied. N. toshimaensis which prefers turbulent areas and $N$. lacunicola which prefers areas affected by laminar-flow share their habitat within the habitat of $N$. bryope which has the most 
facultative habitat preference. $N$. bryope is the facultative inhabitants of holes or barnacle tests, for which both $N$. toshimaensis and $N$. lacunicola are the obligate inhabitants.

7. The origin of the genus Neoclinus was probably not in Japanese waters, but in California or in the New World tropics. On the emigration of the present three Japanese species, two possible cases could be estimated.

8. In Okinawa and Ogasawara, different from Tanabe Bay, fishes of Neoclinus have many competitors for the holes or barnacle tests. $N$. bryope has more facultative habitat preference and is more facultative inhabitants of holes or barnacle tests than the other two species of Neoclinus. Owing to this fact, only N. bryope might be able to extend to tropics (Okinawa).

\section{REFERENCES}

Araga, C. and H. Tanase, 1966. Inshore fishes of Wakayama Prefecture. Rep. Jap. Ass. Nat. Conserv., 27: 81-95 (In Japanese).

Barbour, T. 1912. Two preoccupied names. Proc. Biol. Soc. Washington, 25: 187.

Fowler, H.W. 1958. A synopsis of the fishes of China, Part VIII. Quart. Jour. Taiwan Mus., $11(3 / 4)$ : 147-339.

Gosline, W.A. 1959. Mode of life, functional morphology, and classification of modern teleostean fishes. Syst. Zool., 8(3): 160-164.

Honma, Y. 1963. Fish-fauna (Agnatha, Chondrichthys, Osteichthys) of Sado Island, Sea of Japan. Publ. Sado Mus., 5: 12-32.

- and C. Sugihara, 1963. A revised list of the blennioid and ophidioid fishes of the suborder Blenniina obtained from the waters of Sado Island, including the area of Yamagata Prefecture, Sea of Japan. Bull. Sado Mus., 11: 5-9 (In Japanese).

Hubbs, C. 1952. A contribution of the classification of the blennioid fishes of the family Clinidae, with a partial revision of the eastern Pacific forms. Stanford Ichth. Bull., 4: 41-165.

- 1953. Revision and systematic position of the blenniid fishes of the genus Neoclinus. Copeia, 1953 (1): 11-23.

Hubbs, G.L. and K.F. Lagler, 1958. Fishes of the Great Lakes Region. Bull. Granbrook Inst. Sci., 26: $1-213$.

Jakubowski, M. 1967. A method for the manifestation of lateral-line canals and their neuromasts in fishes. Copeia, 1967 (1): 234-235.

Jordan, D.S. and J.O. Synder, 1902. A review of the blennioid fishes of Japan. Proc. U.S. Nat. Mus., 25 (1293): 441-504.

- S. Tanaka and J.O. Snyder, 1913. A catalogue of the fishes of Japan. Coll. Sci., Tokyo Imp. Univ., 33: 1-479.

Kamohara, T. 1950. Description of the Fishes from the Province of Tosa and Kishu, Japan. $3+288+$ $5+48+27$ pp. Kochi Society of Education, Kochi" (In Japanese).

1958. A catalogue of fishes Kochi Prefecture (Province Tosa), Japan. Rep. Usa Mar. Biol. Stat., 5 (1): 1-76.

1960. On the shore fishes of Okinoshima and adjacent region, Kochi Prefecture, Japan. Res. Rep. Kochi Univ., Nat. Sci., I, 9(3): 15-30 (In Japanese).

1964. Revised catalogue of fishes of Kochi Prefecture, Japan. Rep. Usa Mar. Biol. Stat., $11(1): 1-99$.

Katayama, M. 1940. A catalogue of the fishes of Toyama Bay. Toyama Hakubutsu Gakkaishi, (3): 1-28 (In Japanese).

Kuroda, N. 1931. A catalogue of the fishes of Shizuura, Surga Japan. Amoeba, 3(1/2): 85-127 (In Japanese). 
1957. A list of the fishes of Nabuto, Boshu, Japan. Zool. Mag., 66(1): 3-5.

Masuda, H., C. Araga and T. Yoshino, 1975. Coastal Fishes of Southern Japan. 379 pp. Tokai Univ. Press, Tokyo.

Matsubara, K. 1955. Fish Morphology and Hierarchy. Part 1. xi+789 pp. Ishizaki Shoten, Tokyo (In Japanese).

Mori, T. 1956. Fishes of San-in district including Oki Islands and its adjacent waters (Southern Japan Sea). Mem. Hyogo Univ. Agricult., 2(3) 1956, Biol. Ser., 2: 1-62 (In Japanese).

Lindberg, G.U. and Z.V. Krasjukowa, 1975. Fishes of the Sea of Japan and the Adjacent Areas of the Sea of Okhotsk and the Yellow Sea. Part 4. 463 pp. Academy of Science of the USSR.

Okada, Y. 1938. A Catalogue of Vertevrates of Japan. iv+412 pp. Maruzen Co., Tokyo.

- and K. Matsubara, 1938. Key to the Fishes and Fish-like Animals of Japan including Kuril Islands, Southern Sakhalin, Bonin Islands, Ryukyu Islands, Korea and Formosa. xl+584 pp. Sanseido Co., Tokyo and Osaka (In Japanese).

Robins, C.R. and J.E. Randall, 1965. Three new western Atlantic fishes of the family Clinidae, with a partial revision of the eastern Pacific forms. Proc. Acad. Nat. Sci. Philadelphia, 117 (6) : 213-234.

Rosenblatt, R.H. and J.S. Stephens, Jr. 1978. Mccoskerichthys sandae, a new and unusual chaenopsid blenny from the Pacific coast of Panama and Costa Rica. Nat. Hist. Mus. Los Angleles County, Contr. in Sci., 293: 1-22.

Shiogaki, M. and Y. Dotsu, 1972. The life history of the bleniid fish, Neoclinus bryope. Bull. Fac. Fisheries, Nagasaki Univ. 34: 1-8.

Smidt, P.J. 1931. Fishes of Japan collected in 1901. Trans. Pacific Comm. Acad. Sci. USSR, 2: 1176.

Smith-Vaniz, W.F. and F.J. Palacio, 1974. Atlantic fishes of the genus Acanthemblemaria, with description of three new species and comments on Pacific species (Clinidae: Chaenopsinae). Proc. Acad. Nat. Sci. Philadelphia, 125 (11): 197-224.

Snyder, J.O. 1912. Japanese shore fishes collected by the United States Bureau of Fisheries Steamer "Albatros" expedition of 1906. Proc. U.S. Nat. Mus., 42: 399-450.

Springer, V.G. 1955. The taxonomic status of the fishes of the genus Stathmonotus, including a review of the Atlantic species. Bull. Mar. Sci. Gulf Caribbean, 5 (1):66-80.

Stephens, J.S., Jr. 1961. Range extension of the temperate blennioid fish, Neoclinus bryope, into the tropical western Pacific. Copeia, 1961 (4): 484-485.

1963. A revised classification of the blennioid fishes of the American Family Chaenopsidae. Univ. California Pub. Zool., 68: 1-165.

- 1970. Seven new chaenopsid blennies from the western Atlantic. Copeia 1970 (2): 280-309.

Tarp, F.H. 1952. A revision of the family Embiotocidae (the Surfperches). California Fish and Game, Fish Bull., 88: 1-99.

Tomiyama, I. 1951. On a Japanese blennioid fish, Zacalles bryope Jordan et Snyder. Zool. Mag., 60 (4) : 8-10.

Ui, H. 1929. Kishu Gyohu. 2nd ed. 284 pp. Takahashi Nanekisha, Osaka (In Japanese). 
Plate I. Specimens of the three Japanese species of Neoclinus.

A: Neoclinus toshimaensis n. sp. Holotype, FAKU 48522.

B: Neoclinus lacunicola n. sp. Holotype, FAKU 49521.

C: Neoclinus bryope (Jordan and Snyder) above: barred pattern specimen, FAKU 48538-a; below: plain pattern specimen, FAKU 49539-c.

Plate II. Living individuals of the three Japanese species of Neoclinus in Tanabe Bay.

A: Neoclinus bryope, in a small rock hole.

B: Neoclinus lacunicola, in a small rock hole.

C: Neoclinus toshimaensis, in a empty shell of Balanus tintinnabulum volcano. 
Publ. Seto Mar. Biol. Lab., XXV (1/4), 1980.

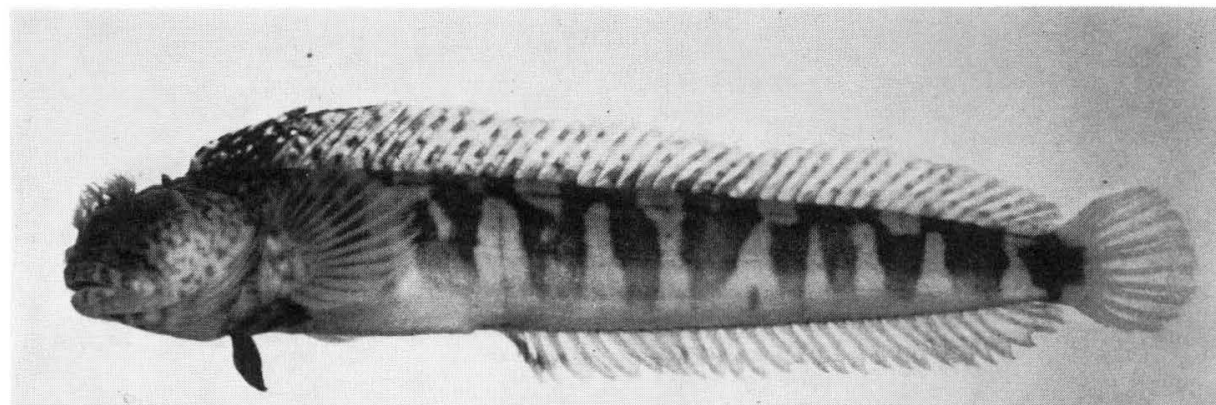

A

B
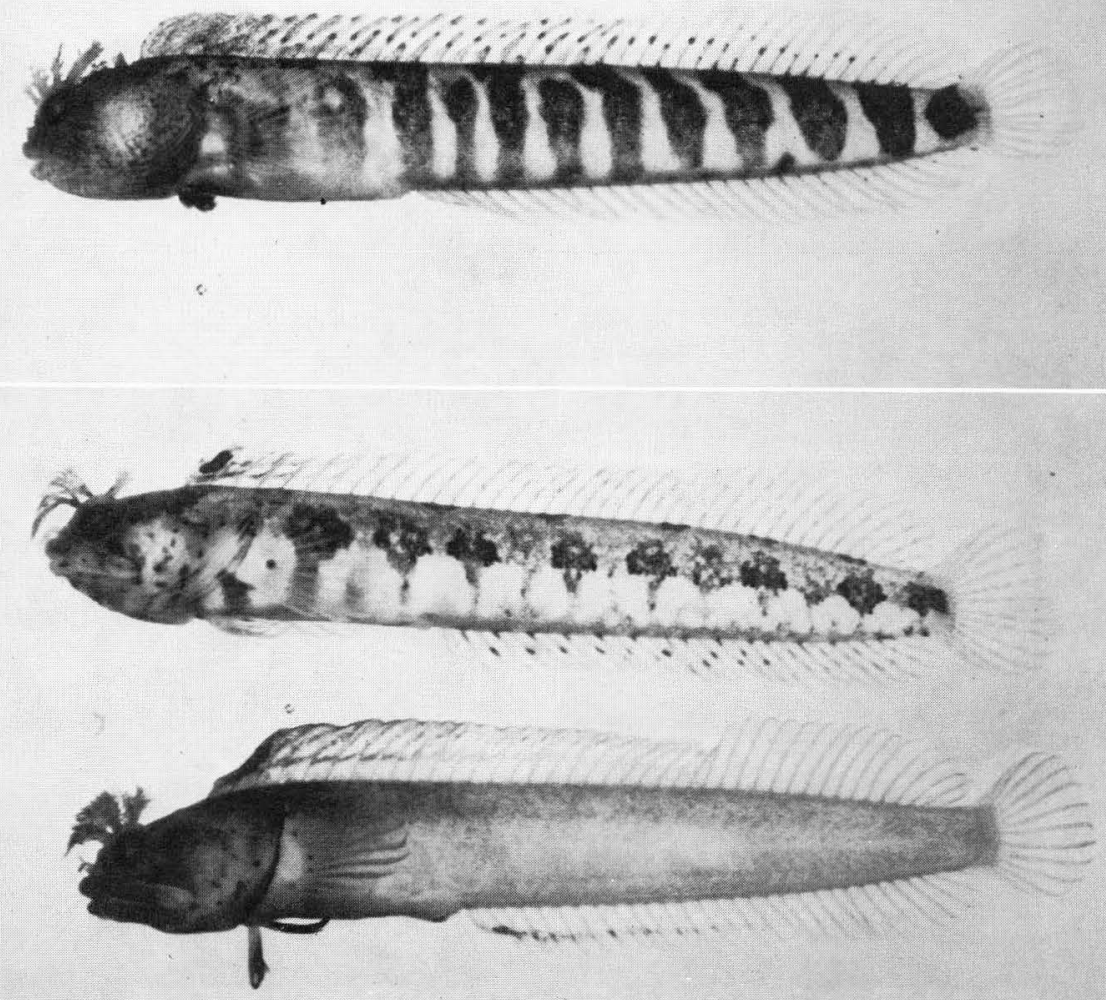

R. Fukao: Review of Genus Neoclinus 
Publ. Seto Mar. Biol. Lab., XXV (1/4), 1980.

A

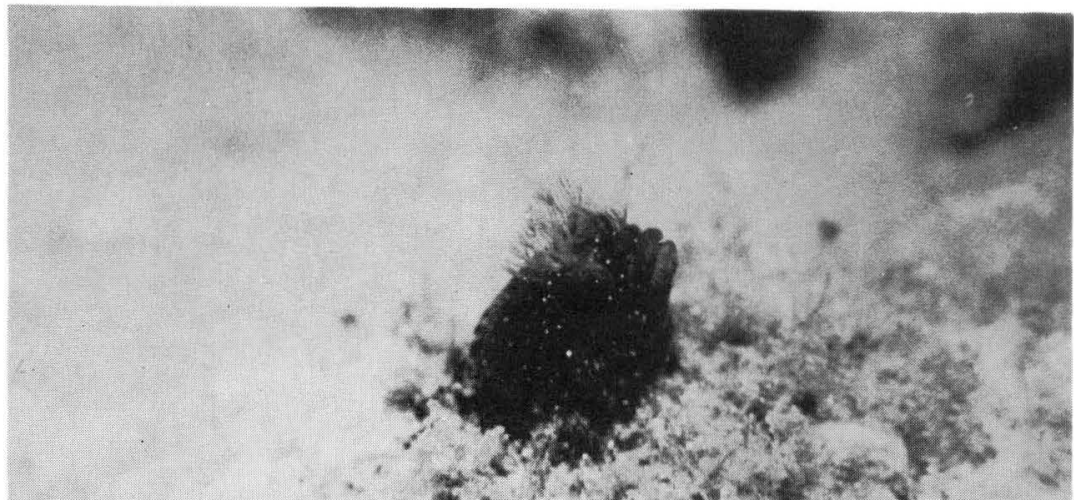

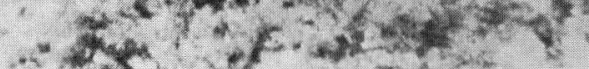
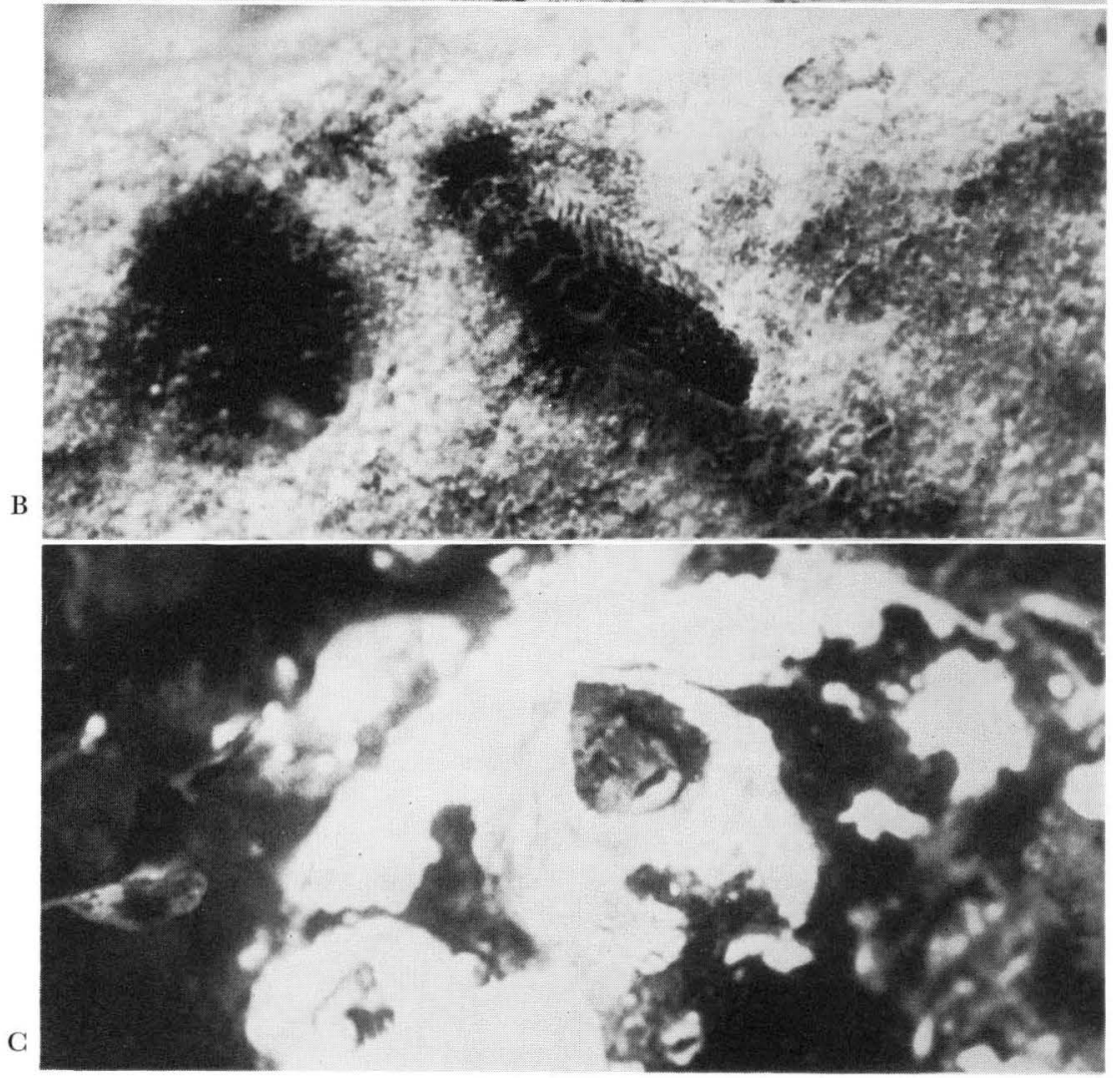

R. Fukao: Review of Genus Neoclinus 